Foss. Rec., 20, 259-278, 2017

https://doi.org/10.5194/fr-20-259-2017

(C) Author(s) 2017. This work is distributed under

the Creative Commons Attribution 4.0 License.

\title{
Koristocetus pescei gen. et sp. nov., a diminutive sperm whale (Cetacea: Odontoceti: Kogiidae) from the late Miocene of Peru
}

\author{
Alberto Collareta $^{1,2}$, Olivier Lambert ${ }^{3},{\text { Christian de } \text { Muizon }^{4}, \text { Mario Urbina }^{5} \text {, and Giovanni Bianucci }}^{1}$ \\ ${ }^{1}$ Dipartimento di Scienze della Terra, Università di Pisa, via Santa Maria 53, 56126 Pisa, Italy \\ ${ }^{2}$ Dottorato Regionale in Scienze della Terra Pegaso, Università di Pisa, via Santa Maria 53, 56126 Pisa, Italy \\ ${ }^{3}$ Institut Royal des Sciences Naturelles de Belgique, D.O. Terre et Histoire de la Vie, rue Vautier 29, 1000 Brussels, Belgium \\ ${ }^{4}$ Département Origines et Évolution, Muséum National d'Histoire Naturelle, Centre de Recherches sur la paléobiodiversité et \\ les paléoenvironnements - CR2P (CNRS, MNHN, UPMC, Sorbonne Université), rue Buffon 8, 75005 Paris, France \\ ${ }^{5}$ Departamento de Paleontologia de Vertebrados, Museo de Historia Natural de la Universidad Nacional Mayor de San \\ Marcos, avenida Arenales 1256, Lima 14, Peru
}

Correspondence to: Alberto Collareta (alberto.collareta@for.unipi.it)

Received: 7 August 2017 - Accepted: 30 October 2017 - Published: 7 December 2017

\begin{abstract}
Among odontocetes, members of the family Kogiidae (pygmy and dwarf sperm whales) are known as smallsized and in many respects enigmatic relatives of the great sperm whale Physeter macrocephalus. Most of the still scanty fossil record of Kogiidae is represented by isolated skulls and ear bones from Neogene deposits of the Northern Hemisphere, with the significant exception of Scaphokogia, a highly autapomorphic genus from late Miocene deposits of the Pisco Formation exposed along the southern coast of Peru. Here we report on a new fossil kogiid from Aguada de Lomas, a site where the late Miocene beds of the Pisco Formation are exposed. This specimen consists of an almost complete cranium representing a new taxon of Kogiidae: Koristocetus pescei gen. et sp. nov. Koristocetus mainly differs from extant Kogia spp. by displaying a larger temporal fossa and well-individualized dental alveoli on the upper jaws. Coupled with a relatively elongated rostrum, these characters suggest that Koristocetus retained some degree of raptorial feeding abilities, contrasting with the strong suction feeding specialization seen in Recent kogiids. Our phylogenetic analysis recognizes Koristocetus as the earliest branching member of the subfamily Kogiinae. Interestingly, Koristocetus shared the southern coast of present-day Peru with members of the genus Scaphokogia, whose unique convex rostrum and unusual neurocranial morphology seemingly indicate a peculiar foraging specialization that has still to be understood. In conclusion, Koristocetus evokes a long history of high diversity, morphological disparity, and sympatric
\end{abstract}

habits in fossil kogiids, thus suggesting that our comprehension of the evolutionary history of pygmy and dwarf sperm whales is still far from being exhaustive.

\section{Introduction}

Among extant odontocetes, members of the currently monotypic family Kogiidae (Kogia breviceps and K. sima, pygmy and dwarf sperm whales) are known as small-sized and in many respects enigmatic relatives of the great sperm whale, Physeter macrocephalus. In spite of their wide geographic distribution, the natural history of pygmy and dwarf sperm whales remains largely speculative, and most of our knowledge about them comes from the study of stranded individuals (e.g., Nagorsen, 1985; McAlpine, 2002; Bloodworth and Odell, 2008; Taylor et al., 2012a, b, and references therein). The still scanty fossil record of Kogiidae is mostly represented by isolated skulls and ear bones from Neogene deposits of the Northern Hemisphere (e.g., Barnes, 1973, 1998; Pilleri, 1987; Whitmore, 1994; Bianucci, 1996, 1997; Cigala Fulgosi, 1996; Luo and Marsh, 1996; Bianucci et al., 1998, 2011; Bianucci and Landini, 1999; Lambert, 2008; Whitmore and Kaltenbach, 2008; Velez-Juarbe et al., 2015, 2016), with the significant exception of Scaphokogia, a highly autapomorphic genus from the late Miocene marine deposits of the Pisco Formation exposed along the southern coast of Peru (de Muizon, 1988). The aim of this paper is the 
description of another kogiid cranium from the Pisco Formation referred to a new genus and species. The specimen was discovered in late Miocene beds exposed at the locality of Aguada de Lomas in the Sacaco Basin. We then undertake a phylogenetic analysis of the relationships of this new taxon and briefly discuss its paleobiological meaning.

(ZooBank LSID for Koristocetus gen. nov.: urn:Isid:zoobank.org:act:790FADA0-A6C5-4345-95AE7CD5CF00149D, record created by Alberto Collareta on 30 October 2017)

(ZooBank LSID for Koristocetus pescei sp. nov.: urn:lsid:zoobank.org:act:805D6750-10CF-4FB0-ABDB-

30160400A8D6, record created by Alberto Collareta on 30 October 2017)

\section{Material and methods}

\subsection{Institutional abbreviations}

IRSNB: Institut Royal des Sciences Naturelles de Belgique, Brussels, Belgium; MBMS, Museo Balseros del Mar del Sur, Salango, Ecuador; MGPUF: Museo di Storia Naturale, Sezione di Geologia e Paleontologia, Università degli Studi di Firenze, Florence, Italy; MNHN: Muséum National d'Histoire Naturelle, Paris, France; MSNC: Museo Civico di Storia Naturale di Comiso, Comiso, Italy; MUSM: Museo de Historia Natural de la Universidad Nacional Mayor de San Marcos, Lima, Peru; MUSNAF: Museo di Storia Naturale dell'Accademia dei Fisiocritici, Siena, Italy; UCR: University of California, Riverside, California, USA; USNM: National Museum of Natural History, Smithsonian Institution, Washington DC, USA; ZMA: Zoological Museum Amsterdam, Amsterdam, the Netherlands.

\subsection{Kogiid specimens analyzed for comparison}

In addition to MUSM 888 we have directly examined for comparison the following fossil and extant Kogiidae: Aprixokogia kelloggi Whitmore and Kaltenbach, 2008 (USNM 187015); Kogia breviceps (de Blainville, 1838) (MBMS 4000; MNHN 1976-37; USNM 22015, 22559, 22893, 270979, 283625, 302041, 395699, 504314; ZMA 14.817, 14.818); Kogia pusilla (Pilleri, 1987) (MGPUF 1540V); Kogia sima (Owen, 1866) (MSNC 3450; MUSNAF Mam410; USNM 550482, 550487, 573734; ZMA 14.765); Praekogia cedrosensis (UCR 15229); Scaphokogia cochlearis de Muizon, 1988 (MNHN PPI 229, MUSM 971, MUSM 1998); Scaphokogia sp. (MUSM 972); Scaphokogiinae sp. (MUSM 3291, MUSM 3405); Thalassocetus antwerpiensis Abel, 1905 (IRSNB M.525).

\subsection{Phylogeny and taxonomy}

The phylogenetic analysis was undertaken with PAUP (Phylogenetic Analysis Using Parsimony; Swofford, 2001) using a modified version of the character-taxon matrix of Lambert et al. (2017) (see appendices A and B for the list of characters and the character-taxon matrix, respectively). We rescored some characters for Scaphokogia cochlearis based on personal observations of two specimens kept at the MUSM and slightly modified characters 29 and 30 in order to better account for the variability recognized in Kogiidae. In addition to MUSM 888, we inserted in our matrix an undescribed taxon of Kogiidae, sharing similarities with Scaphokogia cochlearis and represented by two partial skulls (MUSM 3291 and MUSM 3405) from the highly fossiliferous sites of Cerro Los Quesos (Lambert et al., 2009; Gariboldi et al., 2015, 2017; Bianucci et al., 2016a, c; Di Celma et al., 2016; Gioncada et al., 2018) and Cerro Blanco (Brand et al., 2004, 2011; Esperante et al., 2008, 2015), respectively (late Miocene, Pisco Formation, Peru).

We used the tree-bisection-reconnection algorithm and the heuristic search option, considering all characters as unordered and unweighted. We used the phylogenetic definitions proposed by Bianucci and Landini (2006) and Lambert (2008) for Physeteroidea, Physeteridae, and Kogiidae. Embracing the subdivision of Kogiidae in subfamilies proposed by de Muizon (1988) and then reappraised by Bianucci and Landini (1999), Lambert (2008), and Whitmore and Kaltenbach (2008), here we redefine Kogiinae Gill, 1871 as the most inclusive clade including Kogia but not Scaphokogia, whereas we redefine Scaphokogiinae de Muizon, 1988 as the most inclusive clade including Scaphokogia but not Kogia.

\section{Geographical and stratigraphical framework}

Exposed along the southern coast of Peru, the Pisco Formation is a late Neogene shallow-marine sedimentary unit, known as one of the most impressive Cenozoic marine Fossil Lagerstätten worldwide. Indeed, the fossil record of vertebrates from Pisco Formation stands out for the exceptional abundance of specimens, high diversity and disparity, and remarkable quality of preservation (e.g., Hoffstetter, 1968; de Muizon, 1981, 1984, 1988, 1993; de Muizon and DeVries, 1985; Pilleri, 1989-1990; de Muizon and McDonald, 1995; de Muizon et al., 1999, 2002, 2003, 2004a, b; McDonald and de Muizon, 2002; de Muizon and Domning, 2002; Brand et al., 2004, 2011; Esperante et al., 2008, 2015; Lambert et al., 2008, 2009, 2010a, b, 2015, 2017; Ehret et al., 2009, 2012; Bianucci et al., 2010, 2016a, b, c; Bisconti, 2012; Lambert and de Muizon, 2013; Amson et al., 2014, 2015a, b, 2016; Collareta et al., 2015, 2017b; Esperante and Poma, 2015; Gariboldi et al., 2015; Stucchi et al., 2015, 2016; Gioncada et al., 2016; Marx and Kohno, 2016; Di Celma et al., 2017; 
Landini et al., 2017a, b; Marx et al., 2017; Ramassamy et al., 2017). One of the most significant paleontological sites of the Pisco Formation is Aguada de Lomas (Fig. 1; indicative geographic coordinates: $15^{\circ} 30^{\prime} \mathrm{S} ; 74^{\circ} 48^{\prime} \mathrm{W}$ ), about $8 \mathrm{~km} \mathrm{NNE}$ of the village of Puerto Lomas, within the Neogene Sacaco Basin (de Muizon and DeVries, 1985). According to Lambert and de Muizon (2013), the thick sedimentary succession exposed at Aguada de Lomas includes four vertebrate-bearing levels; namely, ELJ (El Jahuay), AGL (Aguada de Lomas), MTM (Montemar), and SAS (Sud-Sacaco) as defined by de Muizon and DeVries (1985) and de Muizon (1988). The cetacean skull studied here (MUSM 888) was collected about 20 years ago by two of us (Christian de Muizon and Mario Urbina) from the Aguada de Lomas area; it comes from the late Miocene beds of the Pisco Formation located above the AGL vertebrate level of de Muizon and DeVries (1985) (personal observation by Mario Urbina). Therefore, MUSM 888 should be referred to either the MTM or SAS vertebrate levels. These two levels were originally dated to $6.0-5.5 \mathrm{Ma}$ and ca. $5 \mathrm{Ma}$, respectively, based on the composition of the molluscan assemblages and radiometric dating of tuff layers (de Muizon and DeVries, 1985; de Muizon and Bellon, 1986; de Muizon, 1988). More recently, U-Pb dating on zircon grains from tuff layers and Sr-isotope analyses on marine mollusc shells provided new insights into the age of several fossiliferous exposures of the Pisco Formation in the Sacaco Basin (Ehret et al., 2012). In particular, for the SAS level, these geochemical methods yielded ages of $7 \pm 1 \mathrm{Ma}$ $(\mathrm{U}-\mathrm{Pb})$ and ca. $6.59 \mathrm{Ma}$ (strontium ratio); such values are supported by Sr-isotope analyses on shells, collected at the site of Sud-Sacaco (West) from two mollusc-rich intervals located above the vertebrate-bearing tuff layer discussed by de Muizon and DeVries (1985), resulting in ages of 5.93 and 5.89 Ma, respectively (Ehret et al., 2012). Furthermore, Sr-isotope analyses yielded an age of ca. 7.30 Ma for the MTM vertebrate level, whereas the AGL vertebrate level was younger than $7.46 \mathrm{Ma}$, which in turn represents the estimated age of the beds just above the ELJ vertebrate level (Ehret et al., 2012) (see also Lambert and de Muizon (2013), Collareta et al. (2017a), and Lambert et al. (2017) for a discussion about the chronostratigraphic framework of the Pisco Formation cropping out in the Aguada de Lomas valley). Therefore, embracing these recent age estimates, and accounting also for the rather wide confidence intervals associated with the strontium-ratio analyses on shells provided by Ehret et al. (2012), it appears that MUSM 888 should be latest Tortonian or early to mid-Messinian in age.

\section{Systematic paleontology}

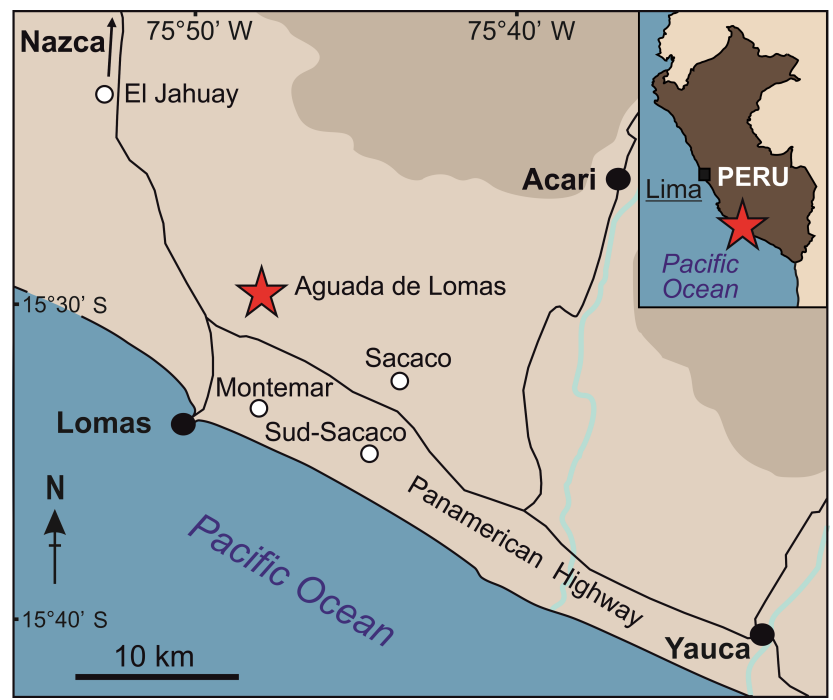

Figure 1. Geographical position (star) of the upper Miocene site of Aguada de Lomas (Pisco Formation, Sacaco Basin, southern coast of Peru, where the holotype of Koristocetus pescei gen. et sp. nov. MUSM 888 was discovered). Modified after Collareta et al. (2017a).

Odontoceti Flower, 1867

Physeteroidea Gray, 1821

Kogiidae Gill, 1871

Kogiinae Gill, 1871

\section{Koristocetus gen. nov.}

Type and only known species: Koristocetus pescei gen. et sp. nov.

Etymology: The generic name originates from the combination of the Greek word koristos, meaning "with helmet" or "crested", for the presence of a well-developed sagittal facial crest, and the Latin word cetus, meaning "whale". Gender masculine.

Known range: Late Miocene (latest Tortonian or early to mid-Messinian, following the chronostratigraphic framework provided by Ehret et al. (2012); see above for more details) of southern Peru.

Differential diagnosis: Same as for the type species until other species are described.

Koristocetus pescei sp. nov.

Figs. 2-5

Cetacea Brisson, 1762

Pelagiceti Uhen, 2008

Neoceti Fordyce and Muizon, 2001

Holotype and only known specimen: MUSM 888, a partial cranium. 
Etymology: The specific name honors the memory and heritage of Hugo Pesce Pescetto (1900-1969), Peruvian physician, politician, writer, and "hero of public health in Peru" (Burstein, 2003), who occupied a position of professor at the Universidad Nacional Mayor de San Marcos, Lima.

Type locality: The holotype is from the locality of Aguada de Lomas, about $8 \mathrm{~km}$ NNE of the village of Puerto Lomas, Arequipa Province, southern coast of Peru (Fig. 1). Indicative geographic coordinates: $15^{\circ} 30^{\prime} \mathrm{S}, 74^{\circ} 48^{\prime} \mathrm{W}$.

Type horizon: Pisco Formation, late Miocene (latest Tortonian or early to mid-Messinian; see above).

Differential diagnosis: Koristocetus is a small-sized physeteroid, similar in size to Kogia spp. and Nanokogia. It is recognized as a kogiid based on the following features: bizygomatic width smaller than $40 \mathrm{~cm}$, presence of a sagittal facial crest, external nares greatly asymmetric, and nasals absent. Differs from Aprixokogia, Kogia, and Thalassocetus by the presence of a more delicate postorbital process of the frontal. Differs from Aprixokogia and Kogia by the smaller angle between the frontal-maxilla suture line and the horizontal plane. Differs from Aprixokogia, Kogia breviceps, and $K$. sima by having a supracranial basin that does not significantly extend onto the dorsal face of the rostrum. Differs from Aprixokogia, Nanokogia, and Praekogia by the foramen magnum being proportionally smaller. Differs from Aprixokogia, Scaphokogia, and Thalassocetus by the antorbital notches extending within the supracranial basin and by the presence of a deep and round notch for the posterior process of the tympanic bulla. Differs from Aprixokogia and Thalassocetus by the slit-like geometry of the antorbital notches. Differs from Kogia, Nanokogia, Praekogia, Scaphokogia, and Thalassocetus by the presence of a single, not subdivided right posterior dorsal infraorbital foramen. Differs from Kogia, Nanokogia, and Praekogia by presenting no lateral expansion of the postnarial eminence of the right premaxilla. Differs from Kogia, Nanokogia, and Thalassocetus by the larger, more anteroposteriorly elongated temporal fossa. Differs from Kogia and Nanokogia by presenting well-individualized dental alveoli on the maxilla. Differs from Kogia and Praekogia by the less posteroventrally elongated postorbital process of the frontal. Differs from Kogia by the proportionally smaller lacrimojugal complex. Differs from Kogia breviceps and K. sima by the proportionally longer rostrum, the supracranial basin not being laterally expanded, the more obliquely oriented frontal groove, and the thin and uninflated lateral maxillary crests. Differs from Kogia sima and Scaphokogia by the lack of a left premaxillary foramen. Differs from Kogia sima by the presphenoid which does not extend anteriorly within the mesorostral groove. Differs from Nanokogia by having a wider mesorostral groove in its posterior portion and a maxilla wider than the premaxilla all along the rostrum. Differs from Praekogia by having the left premaxilla that does not reach the sagittal facial crest and the presphenoid largely exposed on the ventral aspect of the skull. Differs from Scaphokogia by the rostrum having a dorsal face that is not semicylindrical, the postnarial eminence that significantly contributes to the sagittal facial crest, the sagittal facial crest that is not significantly dislocated towards the left side of the skull, the supracranial basin that is not spoon-shaped, and the supraoccipital shield that does not dip anteriorly.

Description, comparisons, and remarks: MUSM 888 is an incomplete skull, lacking parts of the ventral and posterodorsal portions of the braincase, most of the auditory bones, both mandibles, all the teeth, and the left zygomatic process (Figs. 2-5). The rostrum is almost complete. The facial aspect of the skull is generally well preserved, although some surfaces are moderately abraded and the posterior part of the supracranial basin (including the vertex of the skull) is lacking. In ventral view, the surfaces of the squamosals and exoccipitals are poorly preserved. Locally, the skull is still encrusted by hardened sediment. An endocranial cast is preserved as a concretion.

The skull of Koristocetus is small, distinctly asymmetric, with a rather short rostrum (ratio between length of the rostrum and condylobasal length ca. 0.45). Nevertheless, the skull appears anteroposteriorly elongated and drop-shaped in dorsal view (Fig. 2) with respect to Recent kogiids (ratio between condylobasal length and skull width across the postorbital processes ca. 1.7, versus 1.0-1.2 in extant Kogia spp.), thus recalling Nanokogia in this regard (ratio ca. 1.8 in Nanokogia). Sutures between adjacent cranial bones are fused in MUSM 888, thus indicating that it belonged to a full-grown (i.e., physically adult) individual. Measurements of the cranium of Koristocetus are reported in Table 1.

Premaxilla. In dorsal view, the lateral margins of the premaxillae are slightly concave laterally and weakly convergent towards the apex of the rostrum, which in turn presents a significant constriction at mid-length (Fig. 2). Medial to each premaxilla, the mesorostral groove opens starting from the base of the rostrum. It widens progressively towards the anterior tip of the skull as the medial margins of the premaxillae weakly diverge forward, reaching a transverse width of $23 \mathrm{~mm}$ at about two-thirds of the rostrum length (measured from its base). The posterior half of the mesorostral groove is wider than in Nanokogia, recalling instead the condition observed in Aprixokogia and Kogia breviceps. In the posterior half of the rostrum, anterior to the bony nares, the dorsal surface of the right premaxilla is convex transversely, whereas the dorsal surface of the left premaxilla is distinctly concave transversely; both premaxillae progressively flatten towards the apex of the rostrum. No premaxillary foramina are observable on the right and left premaxilla; however, the dorsal surface of the right premaxilla is moderately eroded at the base of the rostrum, and the possibility that a tiny right premaxillary foramen was present cannot be completely ruled 

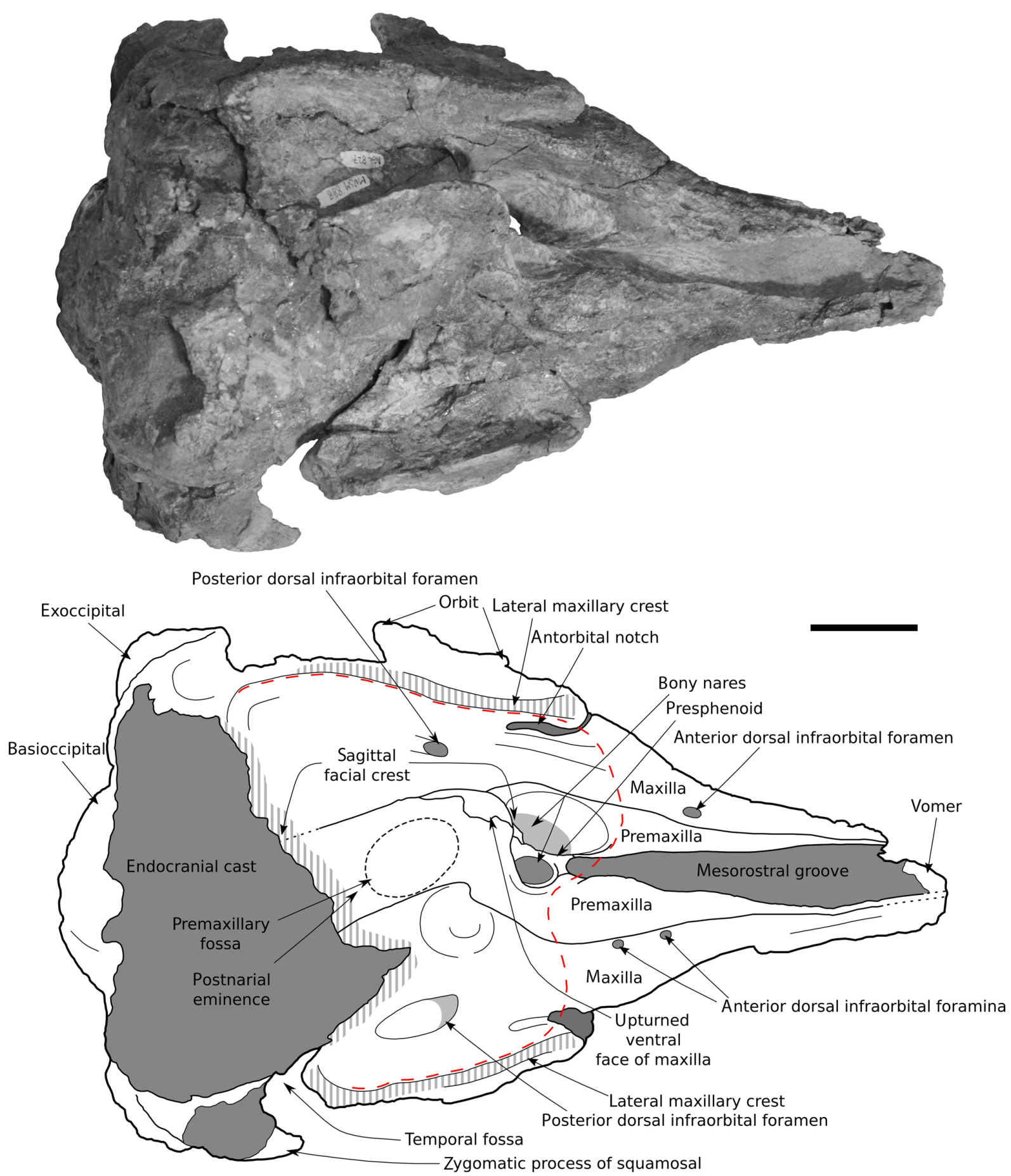

Figure 2. Dorsal view of the skull MUSM 888, holotype of Koristocetus pescei gen. et sp. nov., Pisco Formation, late Miocene of Aguada de Lomas, southern coast of Peru. The dark-grey-shaded areas correspond to hardened sediment. The light-grey-shaded areas correspond to openings in the skull. The grey vertical stripes denote damaged areas. The red dashed line denotes the indicative extent of the supracranial basin. Scale bar: $4 \mathrm{~cm}$. 
out. By contrast, the unambiguous absence of the left premaxillary foramen is a feature shared with Aprixokogia, Kogia breviceps, $K$. pusilla, and Nanokogia, whereas this foramen is present (although reduced in size) in Kogia sima and Scaphokogia. The external nares are observed at the base of the rostrum (Fig. 2). They are strongly asymmetrical and displaced towards the left side of the skull (a feature shared by all Physeteroidea). The left naris is large and oval-shaped; it is anteroposteriorly elongated and is situated in a similarly oriented funnel-shaped depression (a character also observed in Kogia spp.); its transverse diameter is $24 \mathrm{~mm}$. The right naris is significantly smaller than the left one, having a transverse diameter of $9 \mathrm{~mm}$. The left premaxilla presents a lobelike posterior end which forms the anterior and lateral walls of the left naris (a feature reminiscent of Aprixokogia, Kogia, and Nanokogia); as also observed in all Kogiidae except presumably Praekogia, the posterior end of the left premaxilla does not take part in building the sagittal facial crest. In turn, the right premaxilla forms the anterior, lateral, and posterior walls of the right naris. The right premaxilla is constricted transversely at the level of the right naris; posterior to this level, the right premaxilla is significantly expanded posteromedially as a stripe of bone that joins the upturned ventral face of the medial margin of the left maxilla to form the sagittal facial crest (Fig. 2). Such a posterior expansion of the right premaxilla (defined by Whitmore and Kaltenbach, 2008, as the postnarial eminence) is present, more or less developed, in all Kogiidae. The postnarial eminence significantly contributes to build the sagittal facial crest in all Kogiidae except Scaphokogia, in which the right premaxilla constitutes only a small fraction of the supracranial basin and sagittal facial crest, being exposed only at the anterior end of the latter feature. In contrast with Kogia, Nanokogia and, to a lesser extent, Praekogia, no lateral expansion of the postnarial eminence posterior to the right naris is observed in Koristocetus (a feature somewhat reminiscent of Aprixokogia). On this portion of the right premaxilla, which dips anterolaterally, a very shallow depression (premaxillary fossa of Barnes, 1973) occupies the area posterior to the right naris (Fig. 2). This premaxillary fossa is oval-shaped and roughly anteroposteriorly elongated; it measures $37 \mathrm{~mm}$ in length and $27 \mathrm{~mm}$ in width. Several other Kogiidae exhibit a more or less shallow depression located in the right part of the supracranial basin and affecting the right premaxilla (Kogia spp. and Thalassocetus) or both the right premaxilla and maxilla (Praekogia). In extant kogiids, this depression corresponds to the spermaceti chamber hosting the case in which the spermaceti organ is located (Thornton et al., 2015). The posterior half of the facial sagittal crest is not preserved in MUSM 888. In ventral view, the premaxillae are not exposed at the apex of the rostrum (a character shared with Kogia, Nanokogia, and Scaphokogia; for the other fossil kogiids the anterior portion of the rostrum is not known); as such, they bear no teeth.

Maxilla. In dorsal view, the maxilla reaches the anterior end of the skull (Fig. 2). As in Nanokogia, the dorsal expo-
Table 1. Measurements (in mm) of the skull of Koristocetus pescei gen. et sp. nov. (list of measurements modified after Velez-Juarbe et al., 2015).

\begin{tabular}{lr}
\hline Condylobasal length & 321 \\
Length of rostrum & 144 \\
Width of rostrum at base & 107 \\
Height of rostrum at base & 54 \\
Max width of mesorostral groove & 23 \\
Width of rostrum at mid-length & 54 \\
Height of rostrum at mid-length & 34 \\
Width across premaxillae at mid-length of rostrum & 34 \\
Width of mesorostral groove at mid-length of rostrum & 19 \\
Width of rostrum at three-quarters the length, & 42 \\
measured from posterior end & \\
Width of mesorostral groove at three-quarters & 22 \\
the length of rostrum & \\
Distance from tip of rostrum to right external naris & 145 \\
Greatest postorbital width & $185 \mathrm{e}$ \\
Width of left naris & 24 \\
Width of right naris & 9 \\
Maximum width of external nares & 36 \\
Greatest width across premaxillae & 56 \\
Greatest length of temporal fossa & 96 \\
Greatest width of internal nares & 38 \\
Maximum width across occipital condyles & 71 \\
Height of foramen magnum & 20 \\
Width of foramen magnum & 17 \\
\hline
\end{tabular}

sure of the maxilla tapers transversely towards the apex of the rostrum. However, in contrast to Nanokogia, the maxilla is transversely wider than the premaxilla all along the rostrum. Medial and anteromedial to the antorbital notches, the dorsal surface of the maxilla is transversely convex (almost crest-like on the left side of the skull); then it flattens progressively forwards. Both antorbital notches are very narrow, slit-like (as in Kogia, Nanokogia, and Scaphokogia); they enter the supracranial basin (thus resembling Kogia, Nanokogia, and, at least for the right side, Praekogia). Lateral to the antorbital notch, the lateral maxillary crest is sharp and not transversely inflated on both sides (thus differing from those of Kogia breviceps and $K$. sima, resembling instead those of Aprixokogia, K. pusilla, and Scaphokogia). The right and left lateral maxillary crests slightly converge anteriorly and form part of the lateral borders of the supracranial basin. When viewed dorsally, the supracranial basin appears roughly trapezoidal (Fig. 2) as in Kogia pusilla, Nanokogia, and Praekogia, whereas it appears as more laterally and posteriorly expanded (thus appearing roughly semicircular) in K. breviceps, K. sima, and Scaphokogia (the outline of the supracranial basin is poorly preserved in Praekogia and Thalassocetus). As in Kogia pusilla and Scaphokogia, the supracranial basin does not significantly extend onto the dorsal surface of the rostrum (Fig. 2); in turn, in Aprixokogia, Kogia breviceps, and $K$. sima, the anterior part of the supracranial basin is open into the region above the rostrum 
at both sides of the bony nares. Posterior to the antorbital notches, the maxillae form the major part of the floor of the preserved part of the supracranial basin, whose deepest region is located on the right maxilla, posterolateral to the right external naris (a condition reminiscent of what is observed in Aprixokogia and Nanokogia). In extant kogiids, the posterodorsal surface of the right maxilla hosts a wide fossa that accommodates the vocal chamber, in which the vocal cap and the phonic lips (two soft-tissue structures comprising part of the kogiid echolocation system) are situated (Thornton et al., 2015). The upturned median margin of the left maxilla contributes to build the sagittal facial crest, being exposed on the right side of this crest along its dorsal (subhorizontal) edge. The sagittal facial crest is bent leftwards, thus partially hiding the left part of the supracranial basin in dorsal view (a condition reminiscent of Aprixokogia and Kogia pusilla). Two dorsal infraorbital foramina are present on the left maxilla (Fig. 2). The posterior foramen is located posterolateral to the left external naris, roughly at mid-length between the level of the preorbital process and the level of the postorbital process of the frontal; it continues posterolaterally as a short and shallow groove. The anteriormost left dorsal infraorbital foramen is located at about one-third of the length of the rostrum near the maxilla-premaxilla suture; it is anteroposteriorly elongated, with no groove extension. Three dorsal infraorbital foramina are observed on the right maxilla (Fig. 2). The posterior foramen is situated roughly at the same level of the left posterior maxillary foramen; it is large and is followed posterolaterally for about $25 \mathrm{~mm}$ by an elliptical groove. The two anterior right dorsal infraorbital foramina are very small-sized and oval-shaped, located slightly posterior to the level of the left dorsal infraorbital foramen along the maxilla-premaxilla suture. In Kogia, the posterior dorsal infraorbital foramina are commonly subdivided (e.g., duplicated), and a similar condition is observed in Nanokogia, Praekogia, Scaphokogia, and Thalassocetus; in turn, in Aprixokogia, a single posterior dorsal infraorbital foramen is present on each maxilla at the level of the external nares. The palatal exposure of the maxilla is significantly transversely convex in its rostral portion (Fig. 3). Both maxillae bear circular dental alveoli starting from the posterior third of the rostrum. They are shallow, but clearly individualized where the bone surface is nicely preserved; their mean diameter is about $6 \mathrm{~mm}$. Six dental alveoli have been detected on each maxilla; due to poor preservation of the ventral aspect of the anterior half of the rostrum, however, a few more alveoli could have been present. The presence of discrete dental alveoli on the maxillae of MUSM 888 is shared with Aprixokogia and Scaphokogia, whereas just a faint alveolar groove is present in Kogia and Nanokogia (condition unknown in Praekogia and Thalassocetus). We regard the dental alveoli on the maxillae of Koristocetus as presumably bearing functional teeth. The maxillae contact each other medially for about $15 \mathrm{~mm}$ posterior to the posteriormost termination of the left alveolar row. Anterior and posterior to this area, the vomer is exposed between the maxillae. No palatine foramina have been detected on the ventral surface of the maxilla near the contact with the palatine. Posterior to the base of the rostrum, each maxilla projects between the palatine and the lacrimal as a lobe-shaped extension that forms the medial walls of the ventral infraorbital foramen (Fig. 3). This foramen is rather large and oval-shaped; it is elongated along a posteromedial to anterolateral axis, posterolateral to the choanae (i.e., anteromedial to the frontal groove). Anterior to the ventral infraorbital foramen, two shallow depressions are present on each maxilla (Fig. 3); similar features have also been observed in Kogia and Nanokogia and could be related to the anteriormost portion of the pterygoid sinus complex. This interpretation would imply a development of the pterygoid sinus beyond the main fossa outlined in Kogia breviceps by Fraser and Purves (1960: plate 16).

Nasal. As in all Kogiidae known to date, the nasals are absent.

Palatine. Because of the loss of the palatal part of the pterygoid, the ventral surface of the left palatine is clearly observable in MUSM 888; in turn, the right palatine is largely missing, but its outline is nonetheless inferable from the observation of the corresponding suture with the overlying right maxilla. The palatines are located posteromedially to the maxillae and anterolaterally to the choanae; they are anterolaterally bent (i.e., roughly kidney-shaped), and the left palatine is distinctly transversely convex (Fig. 3). A cusp-like projection of the maxillae is present between the palatines (a condition reminiscent of that observed in Scaphokogia). The left palatine contributes to the anterolateral border of the left choana.

Lacrimal + Jugal. As in all kogiids and, more generally, in all Physeteroidea, the boundary between the lacrimal and the jugal is not discernible due to complete fusion. In lateral view, the lacrimojugal complex is roughly triangular (Fig. 4a) and smaller than in Kogia. As observed in Kogia, Nanokogia, and Scaphokogia, the lacrimal contacts the maxilla forming a sigmoidal suture line. The posterodorsal corner of the lacrimal is wedged between the frontal and the maxilla. This portion of the lacrimal is posterodorsally projected as in $\mathrm{Ko}$ gia, Nanokogia, and Praekogia, whereas it is distinctly posteriorly projected in Scaphokogia; it is shorter than in Kogia and Praekogia (where it terminates just anterior to the apex of the orbit) but longer than in Nanokogia and Scaphokogia. The ventralmost tip of the lacrimojugal complex is missing on both sides of the skull. When viewed ventrally, the lacrimojugal complex is posteromedially to anterolaterally elongated and tapers caudally (Fig. 3), thus recalling the condition observed in Nanokogia.

Frontal. The frontal is mostly exposed in lateral and ventral views, the dorsal face of this bone being largely covered by the maxilla. In lateral view, the suture line between the frontal and the maxilla is inclined at about $30^{\circ}$ with respect to the horizontal plane (Fig. 4a), an angle smaller than in Aprixokogia and Kogia but similar to that observed in 

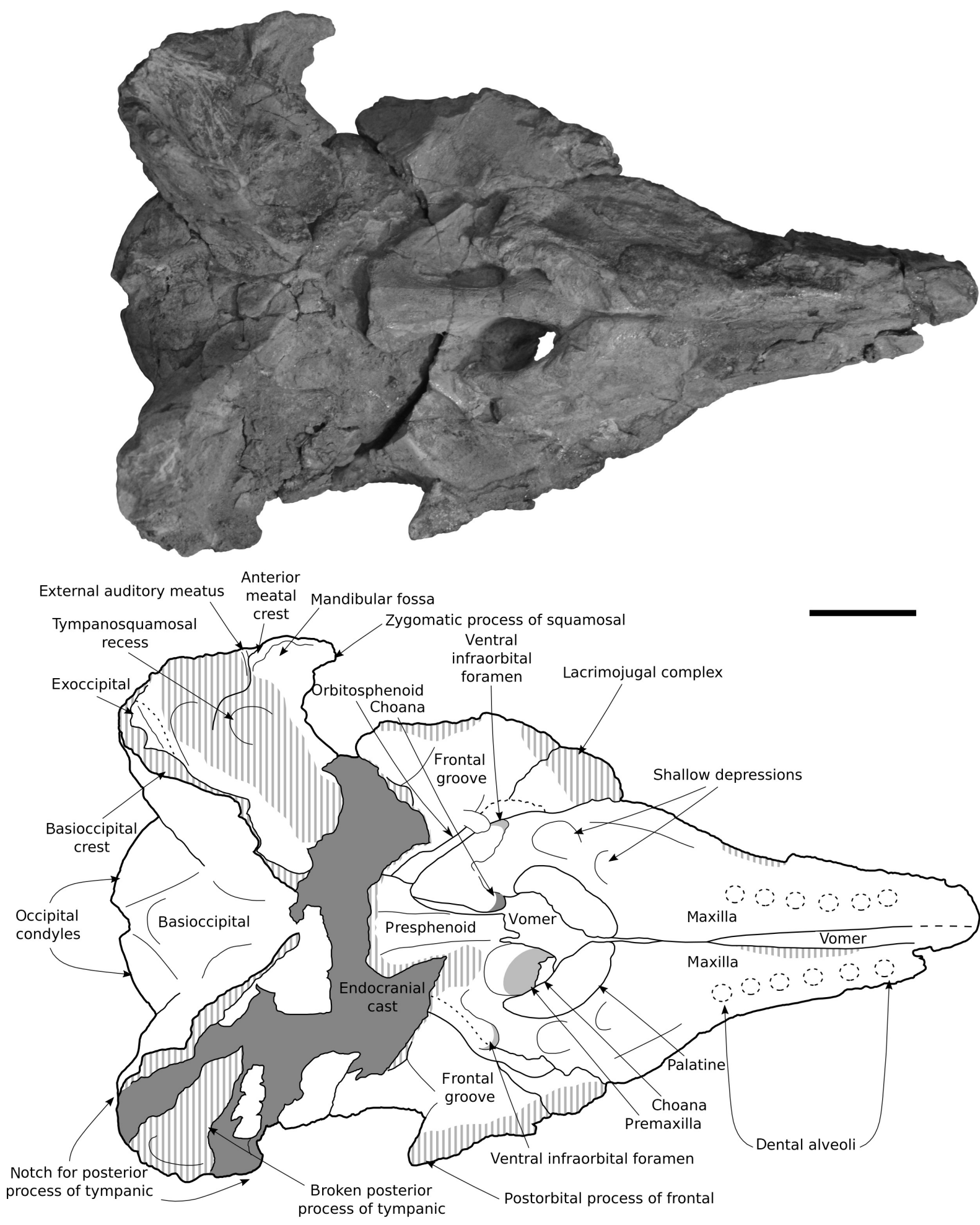

Figure 3. Ventral view of the skull MUSM 888, holotype of Koristocetus pescei gen. et sp. nov., Pisco Formation, late Miocene of Aguada de Lomas, southern coast of Peru. The dark-grey-shaded areas correspond to hardened sediment. The light-grey-shaded areas correspond to openings in the skull. The grey vertical stripes denote damaged areas. Scale bar: $4 \mathrm{~cm}$. 


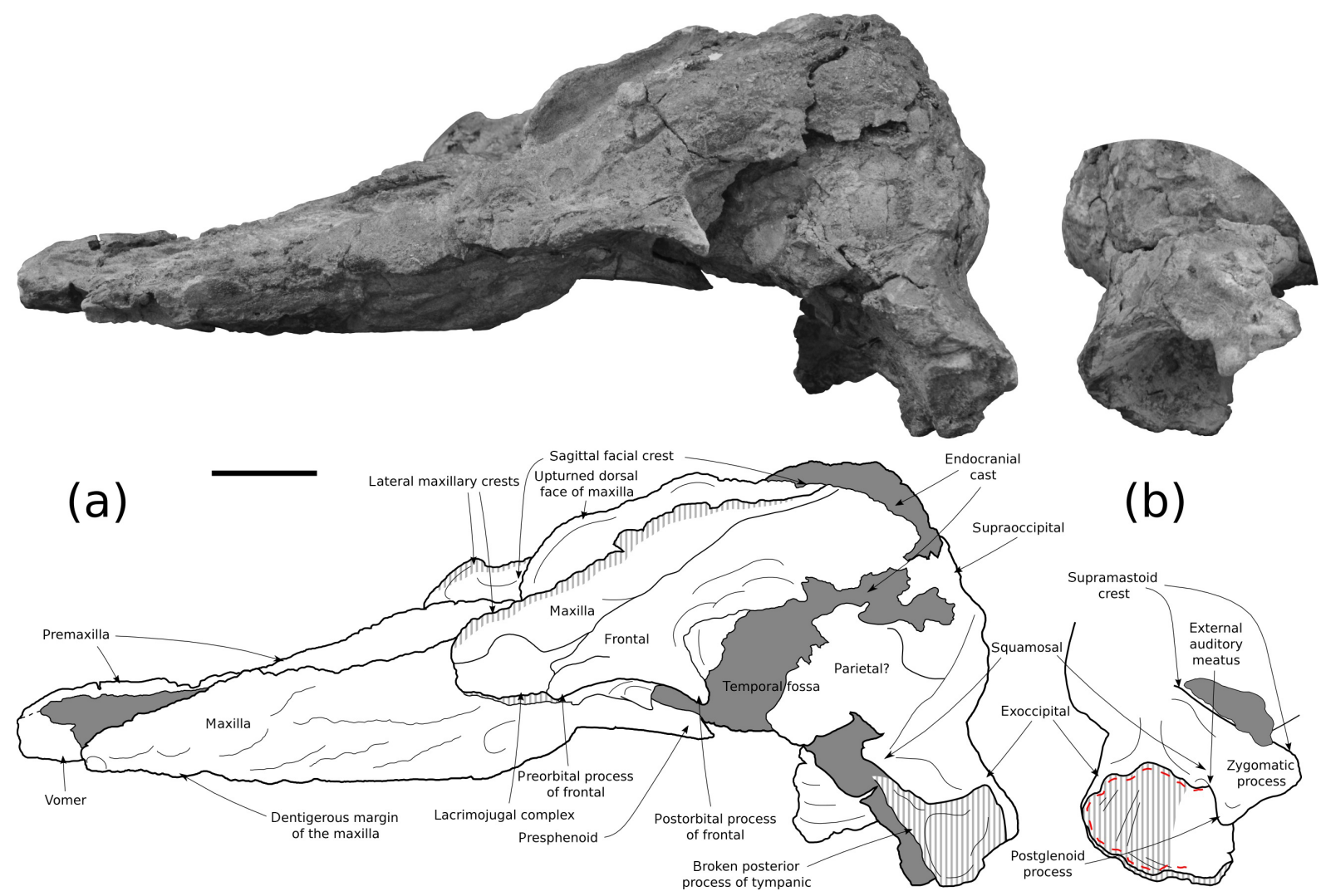

Figure 4. Lateral views of the skull MUSM 888, holotype of Koristocetus pescei gen. et sp. nov., Pisco Formation, late Miocene of Aguada de Lomas, southern coast of Peru. (a) MUSM 888 in left lateral view; (b) MUSM 888 in right lateral view (only a detail of the exoccipital region is shown). The dark-grey-shaded areas correspond to hardened sediment. The grey vertical stripes denote damaged areas. The red dashed line denotes the extent of the notch for the enlarged posterior process of the tympanic bulla. Scale bar: $4 \mathrm{~cm}$.

Nanokogia. When viewed dorsally, the lateral edge of the supraorbital process is slightly S-shaped, being bent medially in its anterior portion and laterally in its posterior portion (Fig. 2). In lateral view, the roof of the orbit is less concave downwards than in Kogia and Nanokogia. The postorbital process is short and slender; it projects posteroventrolaterally. The postorbital process is less massive than in Aprixokogia, Kogia, and Thalassocetus; furthermore, it is less posteroventrally elongated than in Kogia and Praekogia. The frontal constitutes the upper part of the roof of the large temporal fossa. This fossa is large (Figs. 4a, 5a), being distinctly anteroposteriorly longer than the distance between the preorbital process of the maxilla and the anteriormost wall of the temporal fossa; with a ratio between the greatest length of the temporal fossa and the condylobasal length being ca. 0.30, MUSM 888 has a fossa longer than in Nanokogia (ratio in Nanokogia ca. 0.23), contrasting even more with the anteroposteriorly shortened temporal fossa of Kogia and Thalassocetus and resembling instead that of Aprixokogia and Praekogia. The dorsalmost end of the fossa was most likely located near the lost vertex of the skull. The ventral surface of the frontal is only partly preserved in MUSM 888. It displays a wide frontal groove following anterolaterally the optic canal (Fig. 3). The frontal groove widens and flattens anterolaterally; it is more obliquely oriented with respect to the transverse plane than in extant Kogia, thus resembling Nanokogia and other fossil Kogiidae.

Vomer. The vomer reaches the anterior tip of the skull (Figs. 2, 3, 4a, 5a, c). In dorsal view, it forms the floor of the mesorostral groove (Fig. 2). In ventral view, the vomer is exposed along the rostrum as a narrow slit, running anteriorly between the maxillae from the point where they contact each other anterior to the palatines (Fig. 3). Posterior to this level, the vomer covers ventrally the anterior portion of the presphenoid, thus forming the anteromedial segment of the border of the inner nares; it also covers the lateral sides of this bone projecting posteriorly as a pair of slice-like bony projections. This condition recalls that observed in most Kogiidae (Velez-Juarbe et al., 2015: fig. 12) except for Praekogia, in which the vomer partially drapes the ventral surface of the presphenoid.

Sphenoid. In dorsal view, as in all Kogiidae, the presphenoid forms the septum that separates the external nares medially (Fig. 2). It is transversely thin, and its dorsal edge is sharp. The presphenoid does not extend anteriorly within the mesorostral groove, thus differing from many adult speci- 


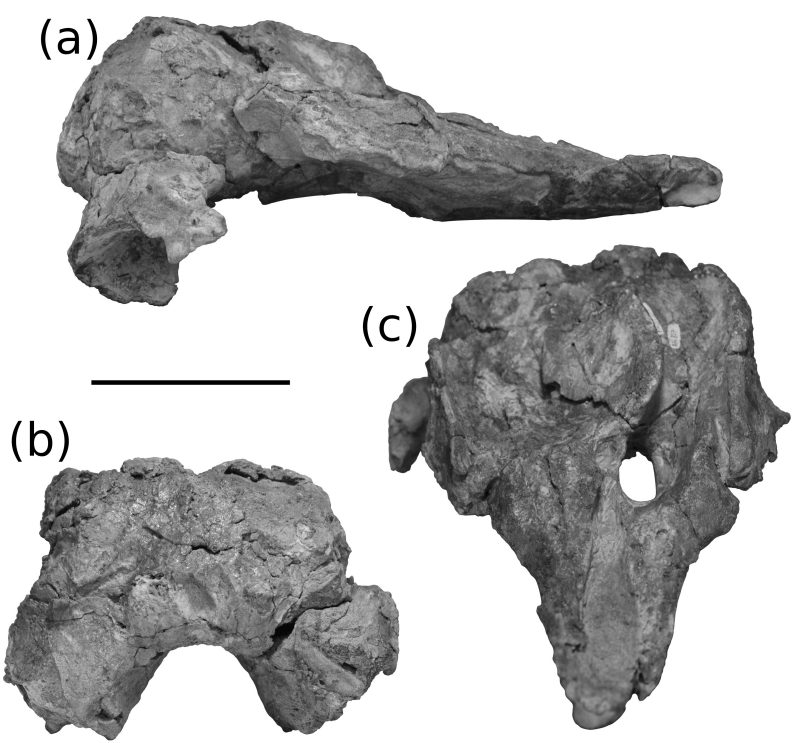

Figure 5. Additional views of the skull MUSM 888, holotype of Koristocetus pescei gen. et sp. nov., Pisco Formation, late Miocene of Aguada de Lomas, southern coast of Peru. (a) Skull in right lateral view; (b) skull in posterior view; (c) skull in anterodorsal view. Scale bar: $10 \mathrm{~cm}$.

mens of Kogia sima and some specimens of Kogia breviceps. In ventral view, the presphenoid is partially exposed, being bordered laterally and anteroventrally by the vomer. Posterior to the inner nares, the presphenoid is robust and expands posterolaterally, thus recalling the shape of an upturned $\mathrm{T}$ (Fig. 3). The orbitosphenoid is probably present in MUSM 888 as a thin, elongated bony slice lying anterior to the anteromedial margin of the optic canal/frontal groove. The orbitosphenoid runs posteromedially-anterolaterally, from the posterolateral corner of the presphenoid towards the posteromedial termination of the lacrimal (Fig. 3). Among Kogiidae, the orbitosphenoid is visible in Aprixokogia, Kogia, and possibly Scaphokogia; apparently, it has not been observed in Nanokogia and Praekogia. Only shreds of the posteriormost portion of the alisphenoid are preserved on both sides of the skull. The basisphenoid is not preserved in MUSM 888.

Pterygoid. Most of the pterygoid is lost on both sides of the skull and only a shred of that bone is tentatively detectable in MUSM 888. It consists of a thin slice of bone located posterolateral to the right bony naris and lateral to the posterior projection of the vomer; it also contacts the frontal (anteriorly), the orbitosphenoid (posterolaterally), and the presphenoid (posteriorly).

Parietal. The parietal is not clearly identifiable but still present in MUSM 888. It likely constitutes most of the posterodorsal portion of the medial wall of the temporal fossa (see description of the frontal bone above).

Squamosal. The zygomatic process is incompletely preserved on the right side of the skull (Figs. 2, 3, 4b, 5a, c). Its proximal portion is triangular in lateral view, and its transverse section is roughly triangular. The supramastoid crest, which represents the anterolateral continuation of the temporal crest, appears as well defined and rather salient. The mandibular fossa is shallow, anteroposteriorly elongated, and facing anteroventrally (Fig. 3). Posteromedial to the mandibular fossa the tympanosquamosal recess is a shallow fossa in which the middle sinus probably resided (Fraser and Purves, 1960: plate 16; see also Barnes, 1973); this depression is observed in Nanokogia and Praekogia and is seemingly less well defined in Kogia. In lateral view, the postglenoid process is robust and triangular in outline (Figs. $4 \mathrm{~b}, 5 \mathrm{a}$ ), with a long, anteroventrally directed posterior wall; it is followed medially by the sharp, spine-like anterior meatal crest. This crest is gently sigmoidal and anterolaterallyposteromedially elongated in ventral view, whereas it is generally more transversely oriented in other Kogiidae for which this feature is known. A narrow groove is observed posterior and parallel to the anterior meatal crest; it is here interpreted as the vestigial external auditory meatus (Fig. 3). Posterior and medial to this level the ventral surface of the squamosal is poorly preserved, and features such as the falciform process and the sutures between the squamosal, the exoccipital, the parietal, and the basioccipital cannot be defined. The posteroventral portion of the squamosal and the anteroventral portion of the paroccipital process of the exoccipital (see below) are shaped as a wide and deep round notch (Figs. 4b, 5a), as in Kogia breviceps, K. sima, Nanokogia, and Praekogia. A similar feature is present but distinctly shallower in Aprixokogia and Scaphokogia, whereas it is not developed in Thalassocetus; as in extant Kogiidae, this notch hosts the inflated posterior process of the tympanic bulla (see below).

Occipital. The basioccipital crests are known only for their posterior portions; they are salient and markedly posterolaterally diverging (Fig. 3), as observed in other Kogiidae. The foramen magnum is roughly oval-shaped (Fig. 5b), higher than wider, and proportionally smaller than in Aprixokogia, Nanokogia, and Praekogia. The occipital shield is only partially preserved: as observed in most Kogiidae, it forms an angle of about $60-70^{\circ}$ with the horizontal plane. The occipital condyles are dorsoventrally elongated and separated ventrally by a shallow furrow. Dorsolateral to the condyles, the shallow dorsal condyloid fossae appear to be present. Lateral and ventrolateral to the condyles, the exoccipitals are broad and flare ventrolaterally to form the paroccipital processes. A reduced jugular notch separates the paraoccipital process of the exoccipital from the basioccipital crest. The preservation of an endocranial cast (Figs. 2, 3, 4a) allows for the reconstruction of the general shape of the braincase of MUSM 888. The two cerebral hemispheres appear as separated dorsally by a wide but shallow longitudinal sulcus, strongly reminiscent of the interhemispheric cleft.

Tympanic bulla. Part of the posterior process of the left tympanic bulla is preserved in MUSM 888 (Figs. 3, 4a). It is broken and its original shape cannot be ascertained. As in extant Kogiidae, the posterior process of the tympanic bulla is 
enlarged and occupies the wide and deep notch present on the posteroventral portion of the squamosal and the anteroventral portion of the paroccipital process of the exoccipital by firmly attaching to the neurocranium.

\section{Phylogeny and paleoecology}

Our phylogenetic analysis resulted in six most parsimonious trees having a consistency index (CI) of 0.5379 and a retention index (RI) of 0.7185 . The strict-consensus tree is shown in Fig. 6. The base of Physeteroidea is marked by a polytomy involving (i) Eudelphis, (ii) a clade embracing the macroraptorial physeteroid genera (i.e., Acrophyseter, Brygmophyseter, Livyatan, and Zygophyseter), and (iii) a clade formed by "Aulophyseter" rionegrensis plus the crown Physeteroidea. Differing form previous phylogenetic analyses of physeteroids (e.g., Lambert et al., 2010, 2017; Boersma and Pyenson, 2015; Velez-Juarbe et al., 2015), our consensus tree recovers all the middle to late Miocene macroraptorial sperm whales (as defined by Lambert et al., 2017) as a monophyletic group, with Livyatan as a sister group of Acrophyseter spp. Crown physeteroids consist of two clades corresponding to the families Physeteridae and Kogiidae. In agreement with Lambert et al. (2017), but differing from other recent analyses (Boersma and Pyenson, 2015; Velez-Juarbe et al., 2015), Orycterocetus and Placoziphius are here recognized as Physeteridae.

All the phylogenetic analyses of Physeteroidea including all extant and fossil kogiids published to date (Bianucci and Landini, 2006; Lambert, 2008; Lambert et al., 2008, 2010, 2017; Boersma and Pyenson, 2015; Velez-Juarbe et al., 2015) agreed on the existence of three groups among Kogiidae: (i) a paraphyletic group including early branching forms such as Aprixokogia and Thalassocetus; (ii) a lineage (subfamily Scaphokogiinae) consisting of the sole bizarre genus Scaphokogia; (iii) a clade (subfamily Kogiinae), sister group to Scaphokogia, whose members are Kogia spp., Nanokogia, and Praekogia. Our cladistic analysis confirms this phylogenetic structure for Kogiidae but identifies a sister group to Scaphokogia in MUSM 3291 and MUSM 3405, which are thus recognized as representatives of a new form of Scaphokogiinae. Although the osteoanatomical differences that separate the four genera of Kogiinae known to date are rather minor, our cladistic analysis is able to fully resolve the phylogenetic relationships among Kogia, Nanokogia, Praekogia, and Koristocetus. The latter genus is here recognized as the earliest branching member of the subfamily Kogiinae, whereas the late Tortonian Nanokogia from Panama, the Messinian Praekogia from Baja California, Mexico, and the late Pliocene to Recent, globally distributed Kogia represent subsequent branches.

Therefore, the late Miocene genus Koristocetus represents the first representative of the subfamily Kogiinae from the Southern Hemisphere, and it retains a series of archaic traits,

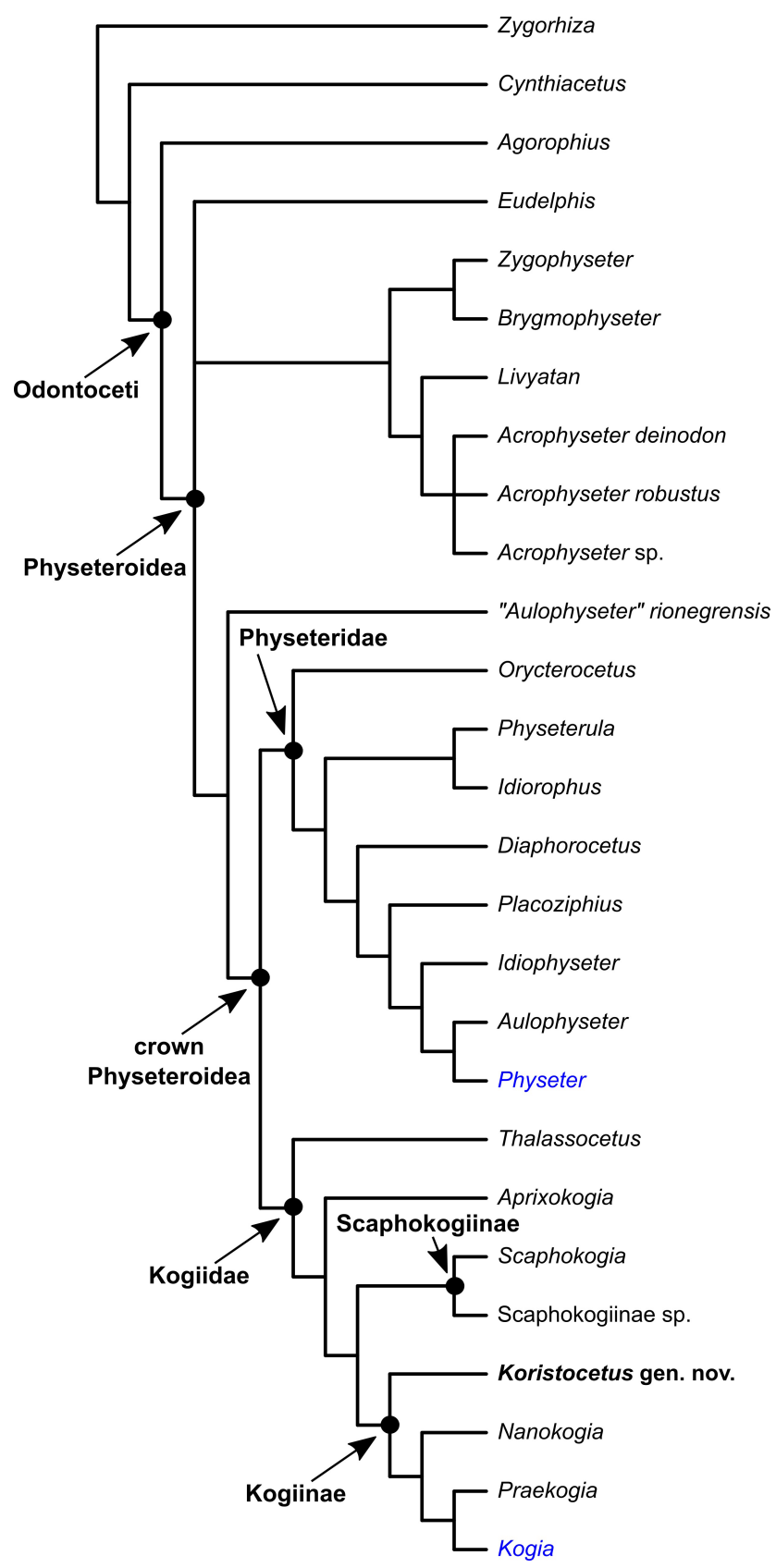

Figure 6. Consensus tree showing the phylogenetic relationships of Koristocetus pescei gen. et sp. nov. with other physeteroids. Acrophyseter sp. refers to MUSM 2182, a partial skull from the site of Cerro Los Quesos (late Miocene, Pisco Formation). Scaphokogiinae sp. refers to MUSM 3291 and MUSM 3405, two partial skulls from the sites of Cerro Los Quesos and Cerro Blanco, respectively (late Miocene, Pisco Formation), representing a new form of Kogiidae sharing similarities with Scaphokogia cochlearis. Extant genera are highlighted in blue.

including the presence of well-individualized dental alveoli on the upper jaws. Extant dwarf and pygmy sperm whales primarily forage on deep-water cephalopods and, secondar- 
ily, on fish and crustaceans; these odontocetes exhibit a strong suction feeding specialization that relies on a peculiar craniomandibular architecture (featuring the proportionally shortest rostrum among Recent cetaceans) and on a highly derived hyoid apparatus (e.g., Caldwell and Caldwell, 1989; McAlpine, 2002; Bloodworth and Marshall, 2005; Werth, 2006; Bloodworth and Odell, 2008; Hocking et al., 2017). As reported above, Koristocetus pescei mainly differs from extant Kogia spp. by displaying a longer rostrum, a larger and more anteroposteriorly elongated temporal fossa, and a presumably functional maxillary dentition. Coupled with a rather robust and not ventrally deflected zygomatic process, these characters suggest that Koristocetus retained some degree of raptorial feeding ability, contrasting with the obvious suction feeding specialization observed in extant dwarf and pygmy sperm whales. The discovery of new specimens of Koristocetus, and especially of remains of the mandibles and hyoid apparatus, will hopefully contribute to clarify the ecology of this fossil kogiid.

During the late Miocene Koristocetus shared the southern coast of present-day Peru with members of the genus Scaphokogia, whose unique pachyostotic and downwardsdeflected semicylindrical rostrum evokes a peculiar feeding/foraging specialization still to be understood. Whereas at least five skulls of Scaphokogia - either collected and deposited in museum collections or still in the field - are known from the late Miocene coastal marine deposits exposed at Aguada de Lomas (Alberto Collareta, personal observation), a single specimen of Koristocetus has been found in the same deposits (and, more generally, from the whole Pisco Formation) to date. Such an uneven distribution could reflect an intense ecospace use of the coastal area of Aguada de Lomas by members of the genus Scaphokogia; in turn, Koristocetus could have exhibited more open-ocean habits, thus recalling the habitat preferences of extant Kogia in this aspect (McAlpine, 2002). However, since skulls of Scaphokogia are much more robust and possibly less prone to degradation than those of other small-sized odontocetes such as Koristocetus, a preservation bias cannot be ruled out.
In conclusion, Koristocetus evokes a long history of high diversity, morphological disparity, and sympatric habits in fossil kogiids (as already highlighted elsewhere; VelezJuarbe et al., 2015, 2016), thus suggesting that our comprehension of the evolutionary history of pygmy and dwarf sperm whales is still far from being exhaustive, especially considering the broad geographical distribution of extant species.

Data availability. No data sets were used in this article. 


\section{Appendix A: List of characters used in the cladistic analysis}

Characters taken from Lambert et al. (2017). Modifications are highlighted in bold.

1. Rostrum length: $\mathbf{0}$, rostrum elongated, ratio between rostrum length and skull width $>1.2 ; \mathbf{1}$, ratio $\leq 1.2$ and $\geq 0.95 ; \mathbf{2}$, short rostrum, ratio $<0.95$.

2. Maxillae, premaxillae and vomer, all reaching the tip of the rostrum which is not formed only by the premaxillae: $\mathbf{0}$, absent; $\mathbf{1}$, present.

3. Supracranial basin of the skull: $\mathbf{0}$, absent; 1, present; $\mathbf{2}$, extended onto the whole dorsal surface of the rostrum.

4. Dorsal exposure of the maxilla on the rostrum: 0, exposure limited to less than half the rostrum length; $\mathbf{1}$, maxilla exposed on more than half the length of the rostrum, narrower than the premaxilla at some levels; 2, wider than the premaxilla all along.

5. Constriction of premaxilla anterior to antorbital notch followed by anterior expansion: $\mathbf{0}$, absent, suture maxilla-premaxilla on the rostrum roughly anteriorly directed; $\mathbf{1}$, present, suture maxilla-premaxilla distinctly anterolaterally directed.

6. Upper tooth row: $\mathbf{0}$, deep alveoli; $\mathbf{1}$, alveoli shallow or absent.

7. Premaxillary teeth: $\mathbf{0}$, present; $\mathbf{1}$, absent. This character cannot be coded for taxa lacking distinct upper alveoli.

8. Maximum width of skull (postorbital or bizygomatic width): $\mathbf{0},<40 \mathrm{~cm} ; \mathbf{1}, \geq 40$ and $<60 \mathrm{~cm} ; \mathbf{2}, \geq 60$ and $<100 \mathrm{~cm} ; \mathbf{3}, \geq 100 \mathrm{~cm}$.

9. Antorbital notch: $\mathbf{0}$, absent; 1, present; $\mathbf{2}$, transformed into a very narrow slit.

10. Right antorbital notch: $\mathbf{0}$, outside the supracranial basin; $\mathbf{1}$, inside the supracranial basin.

11. Number and size of dorsal infraorbital foramina, in the area of the right antorbital notch and posteriorly: $\mathbf{0}$, small to moderate size foramina, at least three-four; $\mathbf{1}$, three large foramina; $\mathbf{2}$, two large foramina; $\mathbf{3}$, one large foramen (maxillary incisure).

12. Right premaxilla: $\mathbf{0}$, posteriorly extended as the left premaxilla; $\mathbf{1}$, more posteriorly extended than the left premaxilla.

13. Right premaxilla: $\mathbf{0}$, not widened posteriorly; $\mathbf{1}$, posterior extremity of the right premaxilla laterally widened, occupying at least one third of the width of the supracranial basin, mostly on the right side.
14. Presence of a sagittal crest: $\mathbf{0}$, absent; $\mathbf{1}$, present as a shelf covered by the pointed right premaxilla.

15. Left premaxillary foramen very small or absent: $\mathbf{0}, a b-$ sent (i.e. foramen present and not reduced); 1 , present.

16. Increase in size of the right premaxillary foramen: $\mathbf{0}$, absent, ratio between width of foramen and width of premaxilla at that level $\leq 0.20 ; 1$, present, ratio $>0.20$.

17. Anteroposterior level of right premaxillary foramen: $\mathbf{0}$, distinctly anterior to antorbital notch; $\mathbf{1}$, slightly anterior to antorbital notch; $\mathbf{2}$, same level or posterior to antorbital notch.

18. Asymmetry of the bony nares: $\mathbf{0}$, absent or reduced; $\mathbf{1}$, strong, left bony naris significantly larger than right naris.

19. Lack of nasals: 0, both nasals present; $\mathbf{1}$, one nasal absent; $\mathbf{2}$, both nasals absent.

20. Widening of the supracranial basin on the right side: $\mathbf{0}$, absent; 1, present, basin overhangs the right orbit.

21. Right maxilla reaching the sagittal plane of the skull on the posterior wall of the supracranial basin: $\mathbf{0}$, absent; $\mathbf{1}$, present.

22. Fusion of lacrimal and jugal: $\mathbf{0}$, absent; 1, present.

23. Projection of the lacrimal-jugal between frontal and maxilla: $\mathbf{0}$, short or absent; $\mathbf{1}$, long.

24. Dorsoventral level of the antorbital process of the frontal: 0, higher than the lateral margin of rostrum base; 1 , at approximately the same level; 2 , considerably lower.

25. Frontal-maxilla suture, with skull in lateral view: $\mathbf{0}$, forming an angle $<15^{\circ}$ from the axis of the rostrum; $1,15-35^{\circ} ; 2,>35^{\circ}$.

26. Temporal fossa: 0, anteroposteriorly longer than distance between preorbital process of the maxilla and anterior wall of temporal fossa; $\mathbf{1}$, approximately same length; $\mathbf{2}$, distinctly shorter.

27. Zygomatic process of squamosal in lateral view: $\mathbf{0}$, ' $\mathrm{L}$ 'shaped with dorsal margin ventrally bending in its posterior portion; 1, triangular, with dorsal margin dorsally bending in its posterior portion.

28. Postglenoid process of the squamosal: $\mathbf{0}$, significantly ventrally longer than post-tympanic process; $\mathbf{1}$, roughly same ventral extent as post-tympanic process. 
29. In lateral view of the skull, wide notch posterior to the postglenoid process of the squamosal for the enlarged posterior process of the tympanic: $\mathbf{0}$, absent; $\mathbf{1}$, present but only partially developed, paraoccipital concavity moderately excavated; 2 , present and well developed, paraoccipital concavity transformed in a wide and deep notch.

30. Occipital shield: $\mathbf{0}$, convex and forming an angle of about $40^{\circ}$ from the axis of the rostrum; 1 , as state 0 with an angle of about $60^{\circ} ; \mathbf{2}$, flat or concave forming an angle of about $90^{\circ} ; 3$, flat or concave forming an angle distinctly greater than $90^{\circ}$.

31. Falciform process of the squamosal: $\mathbf{0}$, contacting the corresponding pterygoid; $\mathbf{1}$, forming a thin plate not contacting the pterygoid; $\mathbf{2}$, reduced to a simple peg or absent.

32. Anterior bullar facet of the periotic: $\mathbf{0}$, very anteroposteriorly elongated; $\mathbf{1}$, reduced; $\mathbf{2}$, absent or very small.

33. Posterior extension of the posterior process of the periotic parallel to the general plane of the bone and not ventrally orientated: $\mathbf{0}$, absent; $\mathbf{1}$, present.

34. Accessory ossicle of the tympanic bulla: $\mathbf{0}$, absent or small; 1, enlarged and partially fused with the anterior process of the periotic.

35. Involucrum of the tympanic bulla with an evident central concavity, visible in ventral and medial views, due to the marked pachyostosis of its anterior and posterior portion: $\mathbf{0}$, absent; $\mathbf{1}$, present.

36. Size of teeth (greatest transverse diameter of root expressed as percentage of the maximum width of skull): $\mathbf{0},<5 \% ; \mathbf{1},>5 \%$. Considering the strong heterodonty in Cynthiacetus and Zygorhiza this character is restricted to single-rooted teeth.

37. Loss of dental enamel: $\mathbf{0}$, absent; $\mathbf{1}$, present.

38. Number of mandibular teeth: $\mathbf{0}, 11 ; \mathbf{1}, 12-14 ; \mathbf{2},>14$.

39. Labiolingual compression of the posterior lower teeth (portion out of the alveolus): $\mathbf{0}$, strong; $\mathbf{1}$, weak or absent.

40. Ventral position of the mandibular condyle: $\mathbf{0}$, absent, well developed angular process; 1 , present, angular process low or absent.

41. Anteroposterior level of last upper alveolus or posterior end of vestigial alveolar groove: $\mathbf{0}$, posterior to antorbital process; 1 , at level of antorbital notch or slightly anterior; $\mathbf{2}$, distinctly anterior to the notch.
42. Lateral margin of the supraorbital process of the maxilla: 0, dorsoventrally thin; 1, significantly dorsoventrally thickened, making a subvertical wall.

43. Postorbital process of the frontal: 0, moderately posteroventrally extended; $\mathbf{1}$, much ventrally extended (vertical length of process equal or greater than horizontal length of orbit), with a correspondingly low position of the zygomatic process of the squamosal.

44. Height of temporal fossa: $\mathbf{0}$, dorsal margin at top of skull or somewhat lower; $\mathbf{1}$, much lower, temporal fossa making less than half the skull height.

45. Contact between jugal and zygomatic process of squamosal: $\mathbf{0}$, anteroposteriorly long contact; $\mathbf{1}$ proportionally short, more rounded contact; 2 , no contact. In specimens with no jugal preserved, the contact surface can sometimes be observed on the zygomatic process (e.g., Orycterocetus crocodilinus USNM 22926).

46. Length of the zygomatic process of the squamosal (horizontal length from anterior tip to posterior margin of squamosal): $\mathbf{0}$, ratio between length of the process and bizygomatic width of skull $>0.35 ; 1$, ratio $<0.35$.

47. Medial to tympanosquamosal recess, deep and rectilinear narrow groove in ventral surface of squamosal, from spiny process area to temporal fossa: $\mathbf{0}$, absent or shallow and poorly delineated; $\mathbf{1}$, present.

48. Dorsal process of the periotic: $\mathbf{0}$, dorsally extended and anteroposteriorly long; $\mathbf{1}$, anteroposteriorly shorter, but dorsally extended beyond the medial margin of the internal acoustic meatus; 2 , dorsally short.

49. Posteromedial outline of the pars cochlaris in dorsal view: 0, angular; 1, flattened, barely convex, and roughly continuous with posterior margin of dorsal process.

50. Curvature of the mandible in lateral view: $\mathbf{0}$, absent or reduced, ventral margin roughly rectilinear or rising moderatly anterodorsally; 1 , conspicuous, ventral margin distinctly convex rising both posterodorsally and anterodorsally; 2, present, ventral margin concave.

51. Symphyseal angle on the mandibles: $\mathbf{0},<35^{\circ} ; \mathbf{1}, 35-$ $55^{\circ} ; 2,>55^{\circ}$.

52. Lateral margin of atlas: $\mathbf{0}$, roughly rectilinear or laterally concave; $\mathbf{1}$, convex, with laterally pointed transverse process at mid-height of the bone. Not applicable to Kogia (single block of cervical vertebrae).

53. Notch in the anterior margin of the basihyal: 0, wide and shallow notch; 1, narrow and deep notch; 2, no notch, rectilinear or convex anterior margin. 


\section{Appendix B: Character/taxon matrix}

Data matrix of 53 characters for three outgroups (Agorophius, Cynthiacetus, and Zygorhiza) and 24 extinct and extant physeteroid taxa (Eudelphis, Zygophyseter, Brygmophyseter, Acrophyseter deinodon, Acrophyseter robustus, Acrophyseter sp., Livyatan, “Aulophyseter" rionegrensis, Orycterocetus, Physeterula, Idiorophus, Diaphorocetus, Placoziphius, Aulophyseter, Physeter, Idiophyseter, Thalassocetus, Aprixokogia, Scaphokogia, Praekogia, Kogia, Koristocetus, Nanokogia, and Scaphokogiinae sp.). Acrophyseter sp. refers to MUSM 2182, a partial skull from the site of Cerro Los Quesos (late Miocene, Pisco Formation). Scaphokogiinae sp. refers to MUSM 3291 and MUSM 3405, two partial skulls from the sites of Cerro Los Quesos and Cerro Blanco, respectively (late Miocene, Pisco Formation), representing a new form of Kogiidae sharing similarities with Scaphokogia cochlearis. Extant genera are underlined. All characters are unordered. 0, primitive state; 1, 2, 3, derived states; a, variable between 0 and 1 ; b, variable between 1 and 2; c, variable between 1,2, and 3; n, character inapplicable; ?, missing character.

\begin{tabular}{|c|c|c|c|c|c|c|c|c|c|c|c|}
\hline & 5 & 10 & 15 & 20 & 25 & 30 & 35 & 40 & 45 & 50 & 53 \\
\hline Zygorhiza & 00000 & $0000 n$ & $? 000 \mathrm{n}$ & $\mathrm{nn} 00 \mathrm{n}$ & $\mathrm{n} 000 \mathrm{n}$ & 00002 & 00000 & 00000 & 0n000 & 00000 & $? 0 ?$ \\
\hline Cynthiacetus & 00000 & 0010n & $? 000 \mathrm{n}$ & $\mathrm{nn} 00 \mathrm{n}$ & $\mathrm{n} 000 \mathrm{n}$ & 00002 & 01000 & 10000 & nn000 & $00 ? 00$ & 000 \\
\hline Agorophius & 010 & $0 ? 01 \mathrm{n}$ & 00000 & $000 n$ & & & & ?0??? & $1000 ?$ & 0???? & ??? \\
\hline Eudelphis & $1 ? 0$ & $0 ? 110$ & $01 ? ? 0$ & $? 1 ? 0$ & ???? & $100 ?$ & 1???? & 00??? & ????? & ?0??? & ??? \\
\hline Zygophyseter & 110 & 01210 & 21101 & 2111 & $? 1001$ & $0110 ?$ & & & $100 ? 0$ & $0 ? 2 ? 0$ & 11 ? \\
\hline Brygmophyseter & ??1?? & $0 ? 210$ & 21101 & ??1?? & ???11 & 01101 & ????1 & $101 ? 1$ & ???0? & ????0 & $? ? 1$ \\
\hline Acro. dein & 20110 & $001 ? 0$ & $3 ? 100$ & $11 ? 1$ & $0 ? ? 02$ & 1101 & $? 2011$ & 10101 & $1 ? ? 0 ?$ & 01201 & $1 ? ?$ \\
\hline Acro. & 110 & $0 ? 020$ & $2110 ?$ & 1101 & 1002 & 1101 & ???1? & 0??1 & $10 ? 00$ & $01 ? ? 1$ & $? 11$ \\
\hline Acrol & 110 & 00120 & $? ? ? ? 0$ & ??? & $? ? 0 ?$ & $110 ?$ & ????? & $10 ? 01$ & $1 ? 0 ? ?$ & $01 ? ? 1$ & $? ? ?$ \\
\hline Livyatan & 211 & 01320 & $2 ? 1 ? 0$ & ????0 & $? 1 ? 12$ & $01 ? 0 ?$ & ????? & 10011 & $10 ? 0 ?$ & 1???? & $1 ? ?$ \\
\hline 'Aulo.' rionegr. & 110 & 00110 & 11100 & & & & ????? & & $2001 ?$ & & ??? \\
\hline Ory & & & & & & & & & & & $? ? ?$ \\
\hline Phy & $10 ?$ & $0 ? 210$ & 21101 & $? ? 1 ? 0$ & & 2 & & & $000 ?$ & $? 0$ & $1 ? ?$ \\
\hline Idiorophus & 0110 & 00210 & ????? & ????0 & ???11 & ????? & ????? & & $? 0 ? 0 ?$ & ????0 & ??? \\
\hline Diaphorocetus & $? ? 110$ & $0 ? 120$ & $? 1101$ & $11 ? ? 0$ & ???1? & $1110 ?$ & ????? & $? ? 2 ? ?$ & $20 ? 1 ?$ & $10 ? ? ?$ & ??? \\
\hline Placo & & $? ? 110$ & & & & & $2 ? ?$ & ????? & $20 ? ? ?$ & ?0??? & $? 0$ ? \\
\hline Aulo & & $\ln 2$ & 21101 & & & & $? 201 ?$ & ? & 200?? & $1010 ?$ & ??? \\
\hline Physeter & $022 a$ & $\ln 310$ & 31101 & 02110 & 01022 & 21102 & 22011 & 0121a & 20011 & 10110 & 102 \\
\hline$\overline{\text { Idiophyseter }}$ & ????? & $1 ? 1 ? 0$ & $2110 ?$ & $121 ? 0$ & $? ? ? 22$ & $1 ? ? ? 2$ & ????? & ????? & ????? & ????? & $? ? ?$ \\
\hline Thalassocetus & ????? & $? ? 010$ & $1101 ?$ & ???20 & $1 ? ? 11$ & $? 1101$ & ????? & ????? & $? 011 ?$ & ????? & ??? \\
\hline Aprixokogia & & $0 ? 010$ & 01111 & & & & & ????? & $1110 ?$ & $10 ? ? ?$ & $? ? ?$ \\
\hline Scaph & & & & & & & & & & 1???? & ??? \\
\hline Praekogia & $? ? ?$ & $? ? 021$ & & $? ? 1$ & & & $2 ? ?$ & ????? & $? 111 ?$ & $10 ? ? ?$ & $? ? ?$ \\
\hline Kogia & 1220 & $1 \mathrm{n} 021$ & 01011 & ob 120 & 11122 & $2102 \mathrm{~b}$ & 22111 & $01 \mathrm{c} 1 \mathrm{a}$ & 21112 & 10212 & $2 ? 2$ \\
\hline$\overline{\text { Koristocetus }}$ & 21120 & 01021 & 31011 & $? ? 120$ & $? 11 ? 1$ & 01121 & ????? & ????? & $2100 ?$ & $1 ? ? ? ?$ & $? ? ?$ \\
\hline Nanokogia & 21110 & $1 \mathrm{n} 021$ & 01011 & $? ? 120$ & 11001 & 01021 & 2???? & $0 ? 11$ ? & 11012 & $10 ? ? 0$ & $1 ? ?$ \\
\hline Scaphokogiinae sp. & $? 1111$ & 01020 & 01011 & 02120 & 11121 & ????3 & ????? & ????? & $2100 ?$ & ????? & $? ? ?$ \\
\hline
\end{tabular}


Author contributions. CM and MU collected and prepared the specimen described here. AC and GB carried out the phylogenetic analysis. AC wrote the paper and prepared the illustrations. AC, OL, $\mathrm{CM}, \mathrm{MU}$, and GB conceived the study, contributed to the description of the specimen, discussed the results, and commented on the manuscript at all stages.

Competing interests. The authors declare that they have no conflict of interest.

Special issue statement. This article is part of the special issue "Secondary adaptation of tetrapods to life in water - Proceedings of the 8th International Meeting, Berlin 2017'. It is a result of the 8th International Meeting on the Secondary Adaptation of Tetrapods to Life in Water, Berlin, Germany, 3-8 April 2017.

Acknowledgements. Special thanks are due to Aldo BenitesPalomino, Rafael Varas-Malca, and Walter Aguirre (Museo de Historia Natural de la Universidad Nacional Mayor de San Marcos) for their most valuable and friendly assistance and fruitful discussion on several aspects of the cetacean assemblage of the Pisco Formation. We are also grateful to Elena Cioppi and Stefano Dominici (Museo di Storia Naturale, Sezione di Geologia e Paleontologia, Università degli Studi di Firenze), Giuseppe Manganelli (Dipartimento di Scienze Fisiche, della Terra e dell'Ambiente, Università di Siena), Fabrizio Cancelli (Museo di Storia Naturale dell' Accademia dei Fisiocritici), Gianni Insacco (Museo Civico di Storia Naturale di Comiso), Daniel Robineau and Christine Lefèvre (Muséum National d'Histoire Naturelle), James G. Mead and Charles W. Potter (National Museum of Natural History, Smithsonian Institution), Lawrence G. Barnes and Vanessa R. Rhue (Natural History Museum of Los Angeles County), and Adri Rol (Zoological Museum Amsterdam) for providing access to specimens under their care. This research was supported by a grant of the Italian Ministero dell'Istruzione dell'Università e della Ricerca (PRIN Project 2012YJSBMK) to Giovanni Bianucci. Alberto Collareta received support from the SYNTHESYS Project http://www.synthesys.info/ (Project Number FR-TAF-6129), which is financed by European Community Research Infrastructure Action under the FP7 "Capacities" Program. This paper greatly benefited from constructive comments and thoughtful suggestions by Mark D. Uhen (George Mason University) and Stephen J. Godfrey (Calvert Marine Museum): thank you very much!

An abridged version of the present work was presented at the 8th International Meeting on the Secondary Adaptation of Tetrapods to Life in Water, held at the Museum für Naturkunde (Berlin, Germany) in April 2017; we warmly thank Oliver Hampe and the other members of the hosting committee, as well as all participating researchers, for several fruitful discussions.

Edited by: Oliver Hampe

Reviewed by: Stephen J. Godfrey and Mark D. Uhen

\section{References}

Abel, O.: Les Odontocètes du Boldérien (Miocène supérieur) des environs d'Anvers, Mémoires du Musée Royal d'Histoire Naturelle de Belgique, 3, 1-155, 1905.

Amson, E., de Muizon, C., Laurin, M., Argot, C., and de Buffrénil, V.: Gradual adaptation of bone structure to aquatic lifestyle in extinct sloths from Peru, Proceedings of the Royal Society of London Part B - Biological Sciences, 281, 20140192, https://doi.org/10.1098/rspb.2014.0192, 2014.

Amson, E., Argot, C., McDonald, H. G., and de Muizon, C.: Osteology and functional morphology of the forelimb of the marine sloth Thalassocnus (Mammalia, Tardigrada), J. Mamm. Evol., 22, 169-242, https://doi.org/10.1007/s10914-014-9268-3, 2015a.

Amson, E., Argot, C., McDonald, H. G., and de Muizon, C.: Osteology and functional morphology of the axial postcranium of the marine sloth Thalassocnus (Mammalia, Tardigrada) with paleobiological implications, J. Mamm. Evol., 22 473-518, https://doi.org/10.1007/s10914-014-9280-7, 2015b.

Amson, E., de Muizon, C., and Gaudin, T. J.: A reappraisal of the phylogeny of the Megatheria (Mammalia: Tardigrada), with an emphasis on the relationships of the Thalassocninae, the marine sloths, Zool. J. Linn. Soc.-Lond., 179, 217-236, https://doi.org/10.1111/zoj.12450, 2016.

Barnes, L. G.: Praekogia cedrosensis, a new genus and species of fossil pygmy sperm whale from Isla Cedros, Baja California, Mexico, Contributions in Science of the Natural History Museum of Los Angeles County, 247, 1-20, 1973.

Barnes, L. G.: The sequence of fossil marine mammal assemblages in Mexico, Avances en Investigación, Paleontología de Vertebrados, Publicación Especial, 1, 26-79, 1998.

Bianucci, G.: I cetacei fossili del Museo di Storia Naturale dell'Universita di Pisa, Atti della Societa Toscana di Scienze Naturali, Memorie, Serie A, 103, 63-68, 1996.

Bianucci, G.: The Odontoceti (Mammalia, Cetacea) from Italian Pliocene. The Ziphiidae, Palaeontographia Italica, 84, 163-192, 1997.

Bianucci, G. and Landini, W.: Kogia pusilla from the Middle Pliocene of Tuscany (Italy) and a phylogenetic analysis of the family Kogiidae (Odontoceti, Cetacea), Rivista Italiana di Paleontologia e Stratigrafia, 105, 445-453, https://doi.org/10.13130/2039-4942/5385, 1999.

Bianucci, G. and Landini, W.: Killer sperm whale: a new basal physeteroid (Mammalia, Cetacea) from the Late Miocene of Italy, Zool. J. Linn. Soc.-Lond., 148, 103-131, https://10.1111/j.10963642.2006.00228.x, 2006.

Bianucci, G., Sarti, G., Catanzariti, R., and Santini, U.: Middle Pliocene cetaceans from Monte Voltraio (Tuscany, Italy). Biostratigraphical, paleoecological and paleoclimatic observations, Rivista Italiana di Paleontologia e Stratigrafia (Research In Paleontology and Stratigraphy), 104, 123-130, https://doi.org/10.13130/2039-4942/6122, 1998.

Bianucci, G., Lambert, O., and Post, K.: High concentration of longsnouted beaked whales (genus Messapicetus) from the Miocene of Peru, Palaeontology, 53, 1077-1098, https://10.1111/j.14754983.2010.00995.x, 2010.

Bianucci, G., Gatt, M., Catanzariti, R., Sorbi, S., Bonavia, C. G., Curmi, R., and Varola, A.: Systematics, biostratigraphy and evolutionary pattern of the Oligo-Miocene marine 
mammals from the Maltese Islands, Geobios, 44, 549-585, https://doi.org/10.1016/j.geobios.2011.02.009, 2011.

Bianucci, G., Di Celma, C., Collareta, A., Landini, W., Post, K., Tinelli, C., Muizon, C. de, Bosio, G., Gariboldi, K., Gioncada, A., Malinverno, E., Cantalamessa, G., Altamirano-Sierra, A., Salas-Gismondi, R., Urbina, M., and Lambert, O: Fossil marine vertebrates of Cerro Los Quesos: Distribution of cetaceans, seals, crocodiles, seabirds, sharks, and bony fish in a late Miocene locality of the Pisco Basin, Peru, J. Maps, 12, 1037-1046, https://doi.org/10.1080/17445647.2015.1115785, 2016a.

Bianucci, G., Di Celma, C., Landini, W., Post, K., Tinelli, C., Muizon, C. de, Gariboldi, K., Malinverno, E., Cantalamessa, G., Gioncada, A., Collareta, A., Salas-Gismondi, R., VarasMalca, R. M., Urbina, M. and Lambert, O.: Distribution of fossil marine vertebrates in Cerro Colorado, the type locality of the giant raptorial sperm whale Livyatan melvillei (Miocene, Pisco Formation, Peru), J. Maps, 12, 543-557, https://doi.org/10.1080/17445647.2015.1048315, 2016b.

Bianucci, G., Di Celma, C., Urbina, M., and Lambert, G.: New beaked whales from the late Miocene of Peru and evidence for convergent evolution in stem and crown Ziphiidae (Cetacea, Odontoceti), PeerJ, 4, e2479, https://doi.org/10.7717/peerj.2479, 2016c.

Bisconti, M.: Comparative osteology and phylogenetic relationships of Miocaperea pulchra, the first fossil pygmy right whale genus and species (Cetacea, Mysticeti, Neobalaenidae), Zool. J. Linn. Soc.-Lond., 166, 876-911, https://doi.org/10.1111/j.10963642.2012.00862.x, 2012.

Bloodworth, B. E. and Marshall, C. D.: Feeding kinematics of Kogia and Tursiops (Odontoceti: Cetacea): characterization of suction and ram feeding, J. Exp. Biol., 208, 3721-3730, https://doi.org/10.1242/jeb.01807, 2005.

Bloodworth, B. E. and Odell, D. K.: Kogia breviceps (Cetacea: Kogiidae), Mammalian Species, 812, 1-12, 2008.

Boersma, A. T. and Pyenson, N. D.: Albicetus oxymycterus, a new generic name and redescription of a basal physeteroid (Mammalia, Cetacea) from the Miocene of California, and the evolution of body size in sperm whales, PLOS ONE, 10, e0135551, https://doi.org/10.1371/journal.pone.0135551, 2015.

Brand, L. R., Esperante, R., Chadwick, A. V., Poma, O., and Alomia, M.: Fossil whale preservation implies high diatom accumulation rate in the Miocene-Pliocene Pisco Formation of Peru, Geology, 32, 165-168, https://doi.org/10.1130/G20079.1, 2004.

Brand, L. R., Urbina, M., Chadwick, A. V., Devries, T. J., and Esperante, R.: A high resolution stratigraphic framework for the remarkable fossil cetacean assemblage of the Miocene/Pliocene Pisco Formation, Peru, J. South Am. Earth Sci., 31, 414-425, https://doi.org/10.1016/j.jsames.2011.02.015, 2011.

Brisson, A. D.: Regnum Animale in Classes IX distributum sive synopsis methodica. Edito altero auctior, Theodorum Haak, Leiden, 294 pp., 1762.

Burstein, Z.: Hugo Pesce Pescetto. Revista Peruana de Medicina Experimental y Salud Publica, 20, 172-173, 2003.

Caldwell, D. K. and Caldwell, M. C.: Pygmy sperm whale - Kogia breviceps (de Blainville, 1838); dwarf sperm whale - Kogia simus Owen, 1866, in: Handbook of marine mammals. Volume 4, River dolphins and the larger toothed whales, edited by: Ridgway, S. H. and Harrison, R. J. Academic Press, London, 235260, 1989.
Cigala Fulgosi, F.: Rare oceanic deep water squaloid sharks from the lower Pliocene of the Northern Apennines (Parma Province, Italy), Bollettino della Società Paleontologica Italiana, 34, 301322, 1996.

Collareta, A., Landini, W., Lambert, O., Post, K., Tinelli, C., Di Celma, C., Panetta, D., Tripodi, M., Salvadori, P. A., Caramella, D., Marchi, D., Urbina, M., and Bianucci, G.: Piscivory in a Miocene Cetotheriidae of Peru: first record of fossilized stomach content for an extinct baleen-bearing whale, The Science of Nature, 102, https://doi.org/10.1007/s00114-015-1319-y, 2015.

Collareta, A., Lambert, O., Landini, W., Di Celma, C., Malinverno, E., Varas-Malca, R., Urbina, M., and Bianucci, G.: Did the giant extinct shark Carcharocles megalodon target small prey? Bite marks on marine mammal remains from the late Miocene of Peru, Palaeogeogr. Palaeoclimatol. Palaeoecol., 469, 84-91, https://doi.org/10.1016/j.palaeo.2017.01.001, 2017a.

Collareta, A., Landini, W., Chacaltana, C., Valdivia, W., Altamirano-Sierra, A., Urbina-Schmitt, M., and Bianucci, G.: A well preserved skeleton of the fossil shark Cosmopolitodus hastalis from the late Miocene of Peru, featuring fish remains as fossilized stomach contents, Rivista Italiana di Paleontologia e Stratigrafia, 123, 11-22, https://doi.org/10.13130/20394942/8005, 2017b.

de Blainville, H. M. D.: Sur les cachalots, Annales Françaises et Étrangères d'Anatomie et de Physiologie, 2, 335-337, 1838.

de Muizon, C.: Les Vertébrés de la Formation Pisco (Pérou). Première partie: Deux nouveaux Monachinae (Phocidae, Mammalia) du Pliocène de Sud-Sacaco, Travaux de l'Institut Français d'Études Andines, 22, 1-160, 1981.

de Muizon, C.: Les Vertébrés de la Formation Pisco (Pérou). Deuxième partie: Les Odontocètes (Cetacea, Mammalia) du Pliocène inférieur de Sud-Sacaco, Travaux de l'Institut Français d'Études Andines, 27, 1-188, 1984.

de Muizon, C.: Les Vertébrés de la Formation Pisco (Pérou). Troisième partie: Les Odontocètes (Cetacea, Mammalia) du Miocène, Travaux de l'Institut Français d'Études Andines, 42, 1-244, 1988.

de Muizon, C.: Walrus-like feeding adaptation in a new cetacean from the Pliocene of Peru, Nature, 365, 745-748, https://doi.org/10.1038/365745a0, 1993.

de Muizon, C. and Bellon, H: Nouvelles données sur l'âge de la Formation Pisco (Pérou). Comptes Rendus Hebdomadaires des Séances de l'Académie des Sciences, Paris, Série D, 303, 14011404, 1986.

de Muizon, C. and DeVries, T. J.: Geology and paleontology of late Cenozoic marine deposits in the Sacaco area (Peru), Geologische Rundschau, 74, 547-563, https://doi.org/10.1007/BF01821211, 1985.

de Muizon, C. and Domning, D. P.: The anatomy of Odobenocetops (Delphinoidea, Mammalia), the walrus-like dolphin from the Pliocene of Peru and its palaeobiological implications, Zool. J. Linn. Soc.-Lond., 134, 423-452, https://doi.org/10.1046/j.10963642.2002.00015.x, 2002.

de Muizon, C. and McDonald H. G.: An aquatic sloth from the Pliocene of Peru, Nature, 375, 224-227, https://doi.org/10.1038/375224a0, 1995.

de Muizon, C., Domning, D. P., and Parrish, M.: Dimorphic tusks and adaptive strategies in a new species of walrus-like dolphin 
(Odobenocetopsidae) from the Pliocene of Peru, Comptes Rendus de l'Académie des Sciences, Series II, 329, 449-455, 1999.

de Muizon, C., Domning, D. P., and Ketten D. R.: Odobenocetops peruvianus, the walrus-convergent delphinoid (Mammalia: Cetacea) from the Early Pliocene of Peru, Smithsonian Contributions to Paleobiology, 93, 223-261, 2002.

de Muizon, C., McDonald, H. G., Salas-Gismondi, R., and Urbina, M.: A new early species of the aquatic sloth Thalassocnus (Mammalia, Xenarthra) from the Late Miocene of Peru, J. Verteb. Paleontol., 23, 886-894, https://doi.org/10.1671/2361-13, 2003.

de Muizon, C., McDonald, H. G., Salas-Gismondi, R., and Urbina, M.: The youngest species of the aquatic sloth Thalassocnus and a reassessment of the relationships of the nothrothere sloths (Mammalia: Xenarthra), J. Verteb. Paleontol., 24, 387-397, https://doi.org/10.1671/2429a, 2004a.

de Muizon, C., McDonald, H. G., Salas-Gismondi, R., and Urbina, M.: The evolution of feeding adaptations of the aquatic sloth Thalassocnus, J. Verteb. Paleontol., 24, 398-410, https://doi.org/10.1671/2429b, 2004b.

Di Celma, C., Malinverno, E., Cantalamessa, G., Gioncada, A., Bosio, G., Villa, I.M., Gariboldi, K., Rustichelli, A., Pierantoni, P.P., Landini, W., Tinelli, C., Collareta, A., and Bianucci, G.: Stratigraphic framework of the late Miocene Pisco Formation at Cerro Los Quesos (Ica Desert, Peru), J. Maps, 12, 1020-1028, https://doi.org/10.1080/17445647.2015.1115783, 2016.

Di Celma, C., Malinverno, E., Bosio, G., Collareta, A., Gariboldi, K., Gioncada, A., Molli, G., Basso, D., Varas-Malca, R., Pierantoni, P. P., Villa, I. M., Lambert, O., Landini, W., Sarti, G., Cantalamessa, G., Urbina, M., and Bianucci G.: Sequence stratigraphy and paleontology of the upper Miocene Pisco Formation along the western side of the lower Ica Valley (Ica Desert, Peru), Rivista Italiana di Paleontologia e Stratigrafia, 123, 255-273, https://doi.org/10.13130/2039-4942/8373, 2017.

Ehret, D. J., Hubbel, G., and MacFadden, B. J.: Exceptional preservation of the white shark Carcharodon (Lamniformes, Lamnidae) from the early Pliocene of Peru, J. Verteb. Paleontol., 29, 1-13, https://doi.org/10.1671/039.029.0113, 2009.

Ehret, D. J., MacDaffen, B. J., Jones, D. S., Devries, T. J., Foster, D. A., and Salas-Gismondi, R.: Origin of the White shark Carcharodon (Lamniformes: Lamnidae) based on recalibration of the upper Neogene Pisco Formation of Peru, Palaeontology, 55, 11391153, https://doi.org/10.1111/j.1475-4983.2012.01201.x, 2012.

Esperante, R. and Poma, O.: Taphonomy and palaeopathology of two mysticete whales, upper Miocene Pisco Formation, Peru, Spanish Journal of Palaeontology, 30, 1-14, 2015.

Esperante, R., Brand, L. R., Nick, K. E., Poma, O., and Urbina, M.: Exceptional occurrence of fossil baleen in shallow marine sediments of the Neogene Pisco Formation, Southern Peru, Palaeogeogr. Palaeoclimatol. Palaeoecol. 257, 344-360, https://doi.org/10.1016/j.palaeo.2007.11.001, 2008.

Esperante, R., Brand, L. R., Chadwick, A. V., and Poma, O.: Taphonomy and paleoenvironmental conditions of deposition of fossil whales in the diatomaceous sediments of the Miocene/Pliocene Pisco Formation, southern Peru - A new Fossil-Lagerstätte, Palaeogeogr. Palaeoclimatol. Palaeoecol., 417, 337-370, https://doi.org/10.1016/j.palaeo.2014.09.029, 2015.

Flower, W. H.: Description of the skeleton of Inia geoffrensis and of the skull of Pontoporia blainvillei, with remarks on the system- atic position of these animals in the order Cetacea, Transactions of the Zoological Society of London, 6, 87-116, 1867.

Fordyce, R. E. and de Muizon, C.: Evolutionary history of Cetaceans: a review. In: Secondary Adaptations of Tetrapods to Life in Water, edited by: de Buffrenil, V. and Mazin, J. M. Dr. Pfeil Verlag, Munich, 163-233, 2001.

Fraser, F. C. and Purves, P. E.: Hearing in cetaceans: Evolution of the accessory air sacs and the structure of the outer and middle ear in recent cetaceans, Bulletin of the British Museum (Natural History), Zoology, 7, 1-140, 1960.

Gariboldi, K., Gioncada, A., Bosio, G., Malinverno, G., Di Celma, C., Tinelli, C., Cantalamessa, G., Landini, W., Urbina, M., and Bianucci, G.: The dolomite nodules enclosing fossil marine vertebrates in the East Pisco Basin, Peru: field and petrographic insights into the Lagerstätte formation, Palaeogeogr. Palaeoclimatol. Palaeoecol., 438, 81-95, https://doi.org/10.1016/j.palaeo.2015.07.047, 2015.

Gariboldi, K., Bosio, G., Malinverno, E., Gioncada, A., Di Celma, C., Villa, I. M., Urbina, M., and Bianucci, G.: Biostratigraphy, geochronology and sedimentation rates of the upper Miocene Pisco Formation at two important marine vertebrate fossilbearing sites of southern Peru, Newsletters on Stratigraphy, 50, 417-444, https://doi.org/10.1127/nos/2017/0345, 2017.

Gill, T.: The sperm whales, giant and pygmy, The American Naturalist, 4, 723-743, 1871.

Gioncada, A., Collareta, A., Gariboldi, K., Lambert, O., Di Celma, C., Bonaccorsi, E., Urbina, M., and Bianucci, G.: Inside baleen: exceptional microstructure preservation in a late Miocene whale skeleton from Peru, Geology, 44, 839-842, https://doi.org/10.1130/G38216.1, 2016.

Gioncada, A., Petrini, R., Bosio, G., Gariboldi, K., Collareta, A., Malinverno, E., Bonaccorsi, E., Di Celma, C., Pasero, M., Urbina, M., and Bianucci, G.: Insights into the diagenetic environment of fossil marine vertebrates of the Pisco Formation (late Miocene, Peru) from mineralogical and Sr-isotope data, J. South Am. Earth Sci., 81, 141-152, https://doi.org/10.1016/j.jsames.2017.11.014, 2018.

Gray, J. E.: On the natural arrangement of vertebrose animals, London Medical Repository, 15, 296-310, 1821.

Hocking, D. P., Marx, F. G., Park, T., Fitzgerald, E. M., and Evans, A. R.: A behavioural framework for the evolution of feeding in predatory aquatic mammals, Proceedings of the Royal Society of London Part B - Biological Sciences, 284, 20162750, https://doi.org/10.1098/rspb.2016.2750, 2017.

Hoffstetter, R.: Un gisement de vertébrés tertiaires à Sacaco (SudPèrou) témoin Néogène d'une migration de faunes australes au long de la côte occidentale sud-américaine, Comptes Rendus de l'Académie des Sciences, Séries D, 267, 1273-1276, 1968.

Lambert, O.: Sperm whales from the Miocene of the North Sea: a re-appraisal. Bulletin de l'Institut royal des Sciences naturelles de Belgique, Sciences de la Terre, 78, 277-316, 2008.

Lambert, O. and Muizon, C. de: A new long-snouted species of the Miocene pontoporiid dolphin Brachydelphis and a review of the Mio-Pliocene marine mammal levels in the Sacaco Basin, Peru, J. Verteb. Paleontol., 33, 709-721, https://doi.org/10.1080/02724634.2013.743405, 2013.

Lambert, O., Bianucci, G., and de Muizon, C.: A new stemsperm whale (Cetacea, Odontoceti, Physeteroidea) from the lat- 
est Miocene of Peru, Comptes Rendus Palevol, 7, 361-369, https://doi.org/10.1016/j.crpv.2008.06.002, 2008.

Lambert, O., Bianucci, G., and Post, K.: A new beaked whale (Odontoceti, Ziphiidae) from the middle Miocene of Peru, J. Verteb. Paleontol., 29, 910-922, https://doi.org/10.1671/039.029.0304, 2009.

Lambert, O., Bianucci, G., and Post, K.: Tusk bearing beaked whales from the Miocene of Peru: Sexual dimorphism in fossil ziphiids?, J. Mammal., 91, 19-26, https://doi.org/10.1644/08MAMM-A-388R1.1, 2010a.

Lambert, O., Bianucci, G., Post, K., Muizon, C. de, SalasGismondi, R., Urbina, M., and Reumer, J.: The giant bite of a new raptorial sperm whale from the Miocene epoch of Peru, Nature, 466, 105-108, https://doi.org/10.1038/nature09067, 2010b.

Lambert, O., Collareta, A., Landini, W., Post, K., Ramassamy, B., Di Celma, C., Urbina, M., and Bianucci, G.: No deep diving: evidence of predation on epipelagic fish for a stem beaked whale from the Late Miocene of Peru, Proceedings of the Royal Society of London Part B - Biological Sciences, 282, 20151530, https://doi.org/10.1098/rspb.2015.1530, 2015.

Lambert, O., Bianucci, G., and Muizon, C. de: Macroraptorial sperm whales (Cetacea, Odontoceti, Physeteroidea) from the Miocene of Peru, Zool. J. Linn. Soc.-Lond., 179, 404-474, 2017.

Landini, W., Altamirano-Sierra, A., Collareta, A., Di Celma, C., Urbina, M., and Bianucci, G.: The late Miocene elasmobranch assemblage from Cerro Colorado (Pisco Formation, Peru), J. South Am. Earth Sci., 73, 168-190, https://doi.org/10.1016/j.jsames.2016.12.010, 2017a.

Landini, W., Collareta, A., Pesci, F., Di Celma, C., Urbina, M., and Bianucci, G.: A secondary nursery area for the copper shark Carcharhinus brachyurus from the late Miocene of Peru, J. South Am. Earth Sci., 78, 164-174, https://doi.org/10.1016/j.jsames.2017.07.003, 2017b.

Luo, Z. and Marsh, K.: Petrosal (periotic) and inner ear of a Pliocene kogiine whale (Kogiinae, Odontoceti): implications on relationships and hearing evolution of toothed whales, J. Verteb. Paleontol., 16, 328-348, https://doi.org/10.1080/02724634.1996.10011320, 1996.

Marx, F. G. and Kohno, N.: A new Miocene baleen whale from the Peruvian desert, Roy. Soc. Open Sci., 3, 160542, https://doi.org/10.1098/rsos.160542, 2016.

Marx, F. G., Collareta, A., Gioncada, A., Post, K., Lambert, O., Bonaccorsi, E., Urbina, M., and Bianucci, G.: How whales used to filter: exceptionally preserved baleen in a Miocene cetotheriid, J. Anat., 231, 212-220, https://doi.org/10.1111/joa.12622, 2017.

McAlpine, D.: Pygmy and dwarf sperm whales, In: Encyclopedia of marine mammals, edited by: Perrin, W. F., Würsig, B., and Thewissen, J. G. M., Academic Press, San Diego, 1007-1009, 2002.

McDonald, H. G. and Muizon C., de: The cranial anatomy of Thalassocnus (Xenarthra, Mammalia), a derived nothrothere from the Neogene of the Pisco Formation (Peru), J. Verteb. Paleontol., 22, 349-365, https://doi.org/10.1671/02724634(2002)022[0349:TCAOTX]2.0.CO;2, 2002.

Nagorsen, D. W.: Kogia simus, Mammalian Species, 239, 1-6, 1985.

Owen, R.: On some Indian Cetacea collected by Walter Elliot, Esq. Transactions of the Zoological Society of London, 6, 17-47, 1866.
Pilleri, G.: The Cetacea of the Italian Pliocene with a descriptive catalogue of the species in the Florence Museum of Paleontology, Brain Anatomy Institute, Bern, 1987.

Pilleri, G.: Beiträge zur Paläontologie der Cetaceen Perus + Beiträge zur Paläontologie der Cetaceen und Pinnpedier der Pisco Formation Perus, II, two parts, complete, Brain Anatomy Institute, Bern, 1989-1990.

Ramassamy, B., Lambert, O., Collareta, A., Urbina, M., and Bianucci, G.: Description of the skeleton of the fossil beaked whale Messapicetus gregarius, searching potential proxies for deep diving abilities, Foss. Rec., in press, 2017.

Stucchi, M., Emslie, S. D., Varas-Malca, R. M., and Urbina-Schmitt, M.: A new late Miocene condor (Aves, Cathartidae) from Peru and the origin of South American condors, J. Verteb. Paleontol., 35, e972507, https://doi.org/10.1080/02724634.2015.972507, 2015.

Stucchi, M., Varas-Malca, R. M., and Urbina-Schmitt, M.: New Miocene sulid birds from Peru and considerations on their Neogene fossil record in the Eastern Pacific Ocean, Acta Palaeontologica Polonica, 61, 417-427, https://doi.org/10.4202/app.00170.2015, 2016.

Swofford, D. L.: PAUP* 4.0: Phylogenetic Analysis Using Parsimony (* and other methods), Sinauer Associates, Sunderland, 2001.

Taylor, B. L., Baird, R., Barlow, J., Dawson, S. M., Ford, J. K. B., Mead, J. G., Notarbartolo di Sciara, G., Wade, P., and Pitman, R. L.: Kogia breviceps, The IUCN Red List of Threatened Species 2012: e.T11047A17692192, available at: https://doi.org/10.2305/IUCN.UK.2012.RLTS.T11047A17692192.en (downloaded on 15 June 2017), 2012a.

Taylor, B. L., Baird, R., Barlow, J., Dawson, S. M., Ford, J. K. B., Mead, J. G., Notarbartolo di Sciara, G., Wade, P., and Pitman, R. L.: Kogia sima, The IUCN Red List of Threatened Species 2012: e.T11048A17695273, available at: https://doi.org/10.2305/IUCN.UK.2012.RLTS.T11048A17695273.en (downloaded on 15 June 2017), 2012b.

Thornton, S. W., McLellan, W. A., Rommel, S. A., Dillaman, R. M., Nowacek, D. P., Koopman, H. N., and Ann Pabst, D.: Morphology of the nasal apparatus in pygmy (Kogia breviceps) and dwarf (K. sima) sperm whales, The Anatomical Record, 298, 13011326, https://doi.org/10.1002/ar.23168, 2015.

Uhen, M. D.: New protocetid whales from Alabama and Mississippi, and a new Cetacean clade, Pelagiceti, J. Verteb. Paleontol., 28, 589-593, https://doi.org/10.1671/02724634(2008)28[589:NPWFAA]2.0.CO;2, 2008.

Velez-Juarbe, J., Wood, A. R., De Gracia, C., and Hendy, A. J.: Evolutionary patterns among living and fossil kogiid sperm whales: evidence from the Neogene of Central America, PLOS ONE, 10, e0123909, https://doi.org/10.1371/journal.pone.0123909, 2015.

Vélez-Juarbe, J., Wood, A. R., and Pimiento, C.: Pygmy sperm whales (Odontoceti, Kogiidae) from the Pliocene of Florida and North Carolina, J. Verteb. Paleontol., 36, e1135806, https://doi.org/10.1080/02724634.2016.1135806, 2016.

Werth, A. J.: Mandibular and dental variation and the evolution of suction feeding in Odontoceti, J. Mammal., 87, 579-588, https://doi.org/10.1644/05-MAMM-A-279R1.1, 2006.

Whitmore Jr., F. C.: Neogene climatic change and emergence of the modern whale fauna of the North Atlantic Ocean, in: Contributions in marine mammals paleontology honoring Frank $\mathrm{C}$. 
Whitmore Jr., edited by: Berta, A. and Deméré, T. A., Proc. San Diego Soc. Nat. Hist., 29, 233-227, 1994.
Whitmore Jr., F. C. and Kaltenbach, J. A.: Neogene Cetacea of the Lee Creek Phosphate Mine, North Carolina, Virginia Museum of Natural History Special Publication, 14, 181-269, 2008. 